\title{
HUKUM PIDANA ADAT BADUY DAN RELEVANGINYA DALAM PEMBAHARUAN HUKUM PIDANA
}

\author{
Ferry Fathurokhman SH
}

\begin{abstract}
Hukum pidana adat Baduy merupakan hukum yang tidak tertulis yang mengorientasikan penyelesaian perkara pidana secara integral yang meliputi pemulihan kepentingan korban, kepentingan pelaku dan kepentingan masyarakat. Hukum pidana adat Baduy mengenal berbagai jenis tindak pidana berikut konsep pertanggungjawaban dan sanksi hukumnya.

Hukum pidana adat Baduy juga mengenal tindak pidana santet, konsep pertanggungjawaban pelaku yang menderita kelainan jiwa, dan pidana ganti rugi dengan berbagai karakteristiknya yang perlu dipertimbangkan untuk diakomodir dalam konteks pembaharuan hukum pidana nasional
\end{abstract}

Kata kunci: Hukum pidana adat Baduy, pembaharuan hukum pidana, penyelesaian perkara integral.

\section{BAB I \\ PENDAHULUAN}

\section{A. Latar Belakang}

Pada dasarnya, KUHP yang diberlakukan untuk seluruh wilayah Indonesia merupakan warisan kolonial yang berasal dari Wetboek van Strafrecht voor Nederlandsch Indie (Staatsblad 1915 No 732), sehingga dapat dipahami jika asasasas dan dasar-dasar tata hukum pidana dan hukum pidana kolonial masih tetap bertahan dengan selimut dan wajah Indonesia. ${ }^{1}$ Pemberlakuan KUHP tersebut menjadi keunikan tersendiri manakala sebenarnya Indonesia telah memiliki hukum sendiri, jauh sebelum Belanda datang dan mengenalkan KUHP di Indonesia.

\footnotetext{
${ }^{1}$ Barda Nawawi Arif. RUU KUHP Baru Sebuah Restrukturisasi dan Rekonstruksi Sistem Hukum Pidana Indonesia. Semarang. Penerbit Pustaka Magister. 2008. Hal. 6.
}

Usaha untuk menggali hukum adat yang nota bene hukum tak tertulis di Indonesia ini tak berhenti di masa-masa para ahli hukum (akademisi) pasca kemerdekaan melainkan terus dilakukan berkesinambungan dalam rangka pembaharuan hukum pidana. Hal ini dapat terlihat misalnya dalam pidato pengukuhan Guru Besar Barda Nawawi Arief, menurutnya salah satu kajian alternatif yang sangat mendesak dan sesuai dengan ide pembaharuan hukum nasional adalah kajian terhadap sistem hukum yang hidup di dalam masyarakat. Hal tersebut didasarkan pada beberapa rekomendasi dan amanat hasil Seminar Hukum Nasional, simposium, undang-undang dan berbagai kongres PBB mengenai The Prevention of Crime and the Treatment of Offenders. ${ }^{2}$

Barda Nawawi Arief. Beberapa Aspek
Pengembangan Ilmu Hukum Pidana
(Menyongsong Generasi Baru Hukum Pidana


Diantara beragam hukum adat yang tersebar di Indonesia, hukum adat Baduy adalah salah satu hukum adat yang ada di Indonesia dan berlaku mengatur masyarakat adat Baduy selama ratusan tahun dari generasi ke generasi. Bahkan hingga kini hukum adat Baduy masih berlaku mengikat bagi masyarakat adat Baduy. Baduy adalah sebuah komunitas masyarakat terasing ${ }^{3}$ di Desa Kanekes KecamatanLeuwidamarKabupaten Lebak, Banten. Sebagaimana masyarakat adat pada umumnya, merekapun memiliki hukum adat sendiri yang berlaku mengikat pada masing-masing anggota masyarakatnya, termasuk hukum pidana adat, yang merupakan subsistem dari hukum adat Baduy.

Rekomendasi nasional dan global (Seminar Hukum Nasional dan Kongres

Indonesia). (Pidato Pengukuhan Guru Besar). Semarang. Badan Penerbit Undip. 2007. Hal.3942.

3 Suhada menuliskan penggunaan istilah masyarakat terasing bagi masyarakat Baduy adalah keliru. Masyarakat terasing didefinisikan Departemen Sosial sebagai masyarakat yang terisolasi dan memiliki kemampuan terbatas untuk berkomunikasi dengan masyarakat-masyarakat lain yang lebih maju, sehingga karena itu bersifat terbelakang serta tertinggal dengan proses mengem bangkan kehidupan ekonomi, politik, sosial budaya, keagaman dan ideologi. Masyarakat Baduy, menurut Suhada lebih tepat dikatakan sebagai masyarakat yang mengasingkan diri. Masyarakat Baduy menjalin intensitas komunikasi dengan masyarakat luar melalui kunjungan. Mereka memiliki sistem sendiri dalam pemenuhan sandang, pangan dan papan sehari-hari yang telah dijalani lama turun temurun. Mereka memilih hidup dengan memegang teguh hukum adat yang mereka miliki. Lihat dalam Suhada. Masyarakat Baduy dalam Rentang Sejarah. Dinas Pendidikan Propinsi Banten. 2003. Hal.16.
PBB), usaha dan saran para ahli hukum serta peristiwa pertemuan dua sistem hukum yang pernah terjadi tersebut itulah yang kemudian mengusik rasa ingin tahu peneliti, untuk melakukan penelitian lebih lanjut mengenai sistem hukum adat Baduy, khususnya sistem hukum pidana adat Baduy. Mengingat kenyataan bahwa hukum pidana adat Baduy masih ada dan berlaku mengikat bagi masyarakat Baduy dan juga masyarakat luar Baduy yang berada di kawasan Baduy, sementara pengetahuan mengenai hal tersebut masih sangat minim.

\section{TINJAUAN PUSTAKA}

\section{A. Hukum Adat}

\section{Urgensi Kajian Hukum Adat}

Pentingnya penggalian hukum adat sebelumnya pernah diingatkan oleh Cornelis Van Vollenhoven dalam mengakhiri bukunya yang berjudul penemuan hukum adat:

Jadi, tugas untuk melanjutkan penemuan hukum adat, khususnya mengenai orang Indonesia untuk sementara waktu harus ditanggung oleh mereka (orang Indonesia) yang bertempat tinggal di Hindia Belanda. Hal ini masuk akal, bukan saja mereka merupakan 49.000.000 dari 66.000.000 yang mendiami wilayah Indonesia dari Formosa sampai Madagascar, tetapi pekerjaan pendahuluan sebagian besar telah di- 
lakukan. Papan untuk meloncat telah tersedia bagi mereka. ${ }^{4}$

Barda Nawawi Arief dalam pidato pengukuhan guru besarnya menyatakan bahwa penggalian dan pengembangan nilai-nilai hukum pidana yang hidup di dalam masyarakat bertumpu pada dunia akademik/keilmuan. Barda Nawawi Arief menyebut nilai-nilai hukum yang hidup dalam masyarakat sebagai "batang terandam" yang belum banyak terangkat ke permukaan. Upaya mengangkat batang terandam ini penting dilakukan untuk dikaji secara mendalam sebagai bahan penyusunan hukum nasional. ${ }^{5}$

\section{Adat, Hukum Adat dan Hukum} Kebiasaan (Customary Law).

\section{a. Adat.}

Dalam beberapa literatur, terminologi adat ditengarai berasal dari kata Adah yang dalam bahasa Arab merujuk pada ragam perbuatan yang dilakukan secara berulang-ulang. ${ }^{6}$ Ragam perbuatan yang dilakukan secara berulang-ulang tersebut kemudian yang menjadikan peristilahan Adat sering diasosiasikan dengan kebiasaan. Maka adat kemudian diartikan sebagai perilaku masyarakat yang bersifat

\footnotetext{
${ }^{4}$ Cornelis Van Vollenhoven. Penemuan Hukum Adat (De ontdekking van het adatrecht). Terjemahan Koninklijk Instituut voor Taal-, Land-en Volkenkunde (KITLV) bersama Lembaga IImu Pengetahuan Indonesia (LIPI). Jakarta. Jambatan.1981. HIm.160

5 Barda Nawawi Arief. Beberapa Aspek Pengembangan Ilmu Hukum Pidana (Menyongsong Generasi Baru Hukum Pidana Indonesia). Semarang. Badan Penerbit Undip. 2007. HIm.50.

6 I Gede AB Wiranata. Hukum Adat Indonesia, Perkembangnya dari Masa ke Masa. Bandung. Citra Aditya Bakti. 2005. HIm.3.
}

ajeg, selalu dikerjakan atau perilaku masyarakat yang selalu dilakukan atau dengan kata lain bahwa kebiasaan adalah perilaku masyarakat (anggota-anggota masyarakat secara bersama-sama) yang ajeg atau yang selalu dikerjakan, dan oleh karena itu bersifat wajib. ${ }^{7}$

I Gede AB Wiranata memberikan penegasan makna yang lebih atas pengertian adat. Menurutnya adat diartikan sebagai kebiasaan yang menurut asumsi masyarakat telah terbentuk, baik sebelum maupun sesudah adanya masyarakat. ${ }^{8}$

\section{b. Hukum Adat.}

Sebagaimana halnya dengan Adat, kata Hukum juga berasal dari bahasa Arab hukm, bentuk jamaknya ahkam yang berarti perintah, suruhan atau ketentuan. ${ }^{9}$ Cristian Snouck Hurgronje adalah ahli hukum yang mengenalkan istilah hukum adat (Adatrecht). Hurgronje menggunakan istilah hukum adat pertama kalinya dalam buku De Aceher's (Orangorang Aceh) tahun 1894. Istilah hukum adat digunakannya untuk menyebut sistem pengendalian sosial (social control) yang bersanksi (disebut hukum adat), yang dibedakan dengan istilah adat sebagai sistem pengendali sosial lain yang tidak memiliki sanksi. ${ }^{10}$

\section{c. Hukum Kebiasaan (Customary Law)}

\footnotetext{
7 Dominikus Rato. Pengantar Hukum Adat. Yogyakarta. LaksBang Pressindo. 2009. HIm 5. ${ }^{8}$ Opcit.

9 Dominikus Rato.Pengantar Hukum Adat. Yogyakarta. LaksBang Pressindo. 2009. HIm 4.

10 I Gede AB Wiranata. Hukum Adat Indonesia, Perkembangnya dari Masa ke Masa. Bandung. Citra Aditya Bakti. 2005. HIm.9.
} 
Jurnal Law reform April 2010. Vol.5. No.1

Penyamaan hukum adat dan hukum kebiasaan ini tidak dapat diterima semua pihak. Salah satu tokoh yang berkeberatan berkaitan hal ini adalah Van Dijk:

"Tidaklah tepat menerjemahkan adatrecht menjadi hukum kebiasaan untuk menggantikan hukum adat, oleh karena yang dimaksud dengan hukum kebiasaan adalah "kompleks peraturan-peraturan hukum yang timbul karena kebiasaan", artinya karena telah demikian lamanya orang biasa bertingkahlaku menurut suatu cara tertentu sehingga timbulah suatu peraturan kelakuan yang diterima dan juga yang diinginkan masyarakat, sedang apabila orang mencari sumber yang nyata dari mana peraturan itu berasal, hampir senantiasa akan ditemukan suatu alat perlengkapan masyarakat tertentu dalam lingkungan besar atau kecil sebagai pangkalnya."

Black's Law Dictionary, mengartikan customary law (hukum kebiasaan) sebagai berikut: ${ }^{11}$

- Law consisting of customs that are accepted as legal requirement or obligatory rules of conduct;

- Practise and beliefs that are so vital and intrinsic a part of a social and economic system that they are treated as if they were laws.

\footnotetext{
${ }^{11}$ Bryan A Garner. Black's Law Dictionary. ST.Paul Minn. 1999 (seventh edition). P.391.

Mencermati uraian di atas, pada dasarnya customary law adalah hukum yang bersumber dari kebiasaan yang kemudian diterima sebagai kebutuhan hukum atau kewajiban dalam bertingkah laku. Jadi senada dengan Van Dijk, customary law memiliki penekanan yang lebih pada kebiasaan yang berulang sehingga menjadi sebuah hukum, sementara pada hukum adat meskipun terdapat unsur kebiasaan namun berpangkal pada suatu pranata masyarakat yang memiliki otoritas untuk menetapkannya sebagai sebuah hukum.

Meskipun kemudian hukum adat sering diterjemahkan menjadi customary law dan banyak penulis secara sederhana menyamakannya namun perbedaan mendasar antara keduanya perlu diketahui. Sebagaimana Roelof H Haveman yang menggunakan istilah customary law untuk menerjemahkan hukum adat, namun lebih lanjut Haveman menjelaskan perbedaan keduanya. Dalam bukunya Ia menuliskan: Adat law is customary law. More specifically: adat law is a type of customary law. ${ }^{12}$ Jadi meskipun Haveman menyatakan hukum adat adalah hukum kebiasaan/customary law, namun lebih lanjut Haveman menegaskan bahwa hukum adat adalah salah satu jenis hukum kebiasaan/ customary law.

Penjelasan Haveman tersebut selaras dengan pendapat Van Vollenhoven. Menurut Van Vollenhoven, hukum adat

12 Roelof $\mathrm{H}$ Haveman. The Legality of Adat Criminal Law in Modern Indonesia. Jakarta. Tatanusa. 2002. HIm.5. 
adalah hal lain dari pada hukum kebiasaan (gewoontenrecht) karena termasuk sebagai sumber-sumbernya adalah: peraturan-peraturan desa, peraturan-peraturan dari raja-raja bumi putra, dan peraturan-peraturan fiqh. ${ }^{13}$

\section{Hukum Pidana Adat}

Hukum Pidana Adat atau hukum pidana yang tidak tertulis dalam bahasa Belanda dikenal sebagai ongeschreven strafrecht. ${ }^{14}$ Menurut Soerojo Wignjodipuro diantara bidang hukum adat, hukum pidana adat adalah bidang hukum adat yang eksistensinya terdesak oleh keberadaan hukum kolonial. ${ }^{15}$ Soepomo kemudian menjelaskan lebih lanjut bahwa hukum adat tidak memisahkan antara pelanggaran (perkosaan) hukum yang mewajibkan tuntutan memperbaiki kembali hukum di dalam lapangan hukum pidana (di muka hakim pidana) dan pelanggaran hukum yang hanya dapat dituntut di lapangan hukum perdata (di muka hakim

\footnotetext{
13 Djojodiguno tidak sependapat dengan Van Vollenhoven, menurutnya penyebutan peraturan desa dan peraturan raja ke dalam bilangan hukum adat adalah keliru, sebab menurutnya kedua hal tersebut adalah termasuk kedalam hukum peraturan. Lihat lebih lanjut dalam I Gusti Ketut Sutha. Bunga Rampai Beberapa Aspekta Hukum Adat. Yogyakarta. Liberty.1987.HIm.11.

14 E. Utrecht. Rangkaian Sari Kuliah Hukum Pidana I. Surabaya. Pustaka Tinta Mas. 1994. HIm.7.

15 Soerojo Wignjodipuro. Pengantar dan Asasasas Hukum Adat. Jakarta. Gunung Agung.1982. HIm. 18. Pada umumnya hukum lokal biasanya terdesak oleh hukum kolonial, seperti halnya Indonesia, keberadaan hukum adat Afrika juga terdesak oleh hukum Eropa melalui kolonialisasi. Lihat lebih lanjut dalam Lawrence Meir Friedman.The Horizontal Society. London.Yale University Press. 1999. Pag.128.
}

perdata). ${ }^{16}$ Penjelasan Soepomo tersebut memberikan pemahaman bahwa sebenarnya terminologi hukum pidana dan hukum perdata didalam hukum adat pada dasarnya tidak dikenal.

\section{Sifat Melawan Hukum}

Komariah Emong Sapardjaja mengonsepsikan suatu tindak pidana secara umum dapat terjadi jika perbuatan tersebut memenuhi perumusan delik (legalitas formil), melawan hukum dan pembuat bersalah melakukan perbuatan itu. ${ }^{17}$ Jadi kekakuan dan keberlakuan asas legalitas formil sebenarnya dibatasi dan dimungkinkan untuk dikesampingkan dengan melihat apakah si pelakunya bersalah dan melihat ada tidaknya sifat melawan hukum (wederrechtelijk).

Konsepsi tersebut menjelaskan bahwa salah satu unsur dari tindak pidana adalah unsur sifat melawan hukum. Menurut Soedarto unsur ini merupakan penilaian objektif terhadap perbuatan, dan bukan terhadap si pembuat. ${ }^{18}$

\section{Asas Legalitas Materil dan Kedudukannya dalam Peraturan Perundang-undangan.}

Selain pengakuan asas legalitas materil dalam ajaran hukum pidana. Kedudukan legalitas materil sebenarnya juga telah diakui keberadaan dan keberlaku-

\footnotetext{
16 Soepomo. Bab-bab Tentang Hukum Adat. Jakarta. Pradnya Paramita.1982.HIm.110.

17 Komariah Emong Sapardjaja. Ajaran Sifat Melawan Hukum Materiel dalam Hukum Pidana Indonesia. Bandung. Alumni. 2002. HIm.22.

18 Sudarto. Hukum Pidana I. Semarang. Yayasan Sudarto. 1980. HIm.76.
} 
annya pasca kemerdekaan Indonesia dalam peraturan perundang-undangan.

Berbagai ketentuan peraturan perundang-undangan menjelaskan bahwa kedudukan asas legalitas materil dalam peraturan perundang-undangan diakui keberadaan dan keberlakuannya. Terlebih dalam pasal 24 (amandemen ke-3) UUD 1945 ditegaskan bahwa kekuasaan kehakiman merupakan kekuasaan yang merdeka untuk menyelenggarakan peradilan guna menegakan hukum dan keadilan. Maka pada hakikatnya peradilan diselenggarakan untuk menegakan hukum (recht/ius) dan keadilan, bukan menegakan hukum secara sempit yang sering direduksi menjadi undang-undang (wet/lege). Hukum memiliki makna yang lebih luas dari undang undang, sebab hukum berarti meliputi hukum yang tertulis dan hukum yang tidak tertulis.

\section{Hukum Adat dalam Konsep KUHP}

Sebagaimana diketahui, dalam Seminar Hukum Nasional I Tahun 1963, direkomendasikan agar rancangan kodifikasi hukum pidana nasional selekas mungkin diselesaikan. Maka tahun 1964 dibicarakan konsep KUHP yang pertama. Berturut-turut kemudian ada pula konsep 1971/1972, Konsep 1982/1983 yang kemudian menjadi konsep 1987/1988, Konsep 1991/1992, Konsep 1997/1998 Konsep 2004 sampai dengan 2006/2007. ${ }^{19}$

\footnotetext{
${ }^{19}$ Barda Nawawi Arif. Bunga Rampai Kebijakan Hukum Pidana Perkembangan Penyusunan Konsep KUHP Baru. Jakarta. Kencana Prenada Media. 2008. HIm. 96.

Asas legalitas dalam Konsep KUHP ditempatkan dalam Buku Kesatu Ketentuan Umum. ${ }^{20}$ Sama halnya dengan KUHP, asas legalitas dalam Konsep KUHP juga dirumuskan dalam pasal $1 .^{21}$

Dalam penerapannya, pidana tambahan tersebut (termasuk point e tentang hukum adat/hukum yang hidup) dapat dijatuhkan bersama-sama dengan pidana pokok, sebagai pidana yang berdiri sendiri atau dapat dijatuhkan dengan pidana tambahan lainnya. ${ }^{22}$ Selanjutnya dalam pasal 67 ayat (3), ditegaskan bahwa pemenuhan kewajiban adat atau hukum yang hidup juga dapat dijatuhkan terhadap korporasi meskipun tidak tercantum dalam perumusan tindak pidana. ${ }^{23}$

\section{Sekilas Mengenai Hukum Pidana Adat Baduy}

\footnotetext{
${ }^{20}$ Kecuali Konsep KUHP awal, Konsep KUHP hanya membagi KUHP ke dalam dua buku: Ketentuan Umum (Buku I) dan Tindak Pidana (Buku II).

1 Pada konsep 1997/1998 asas legalitas ditempatkan dalam pasal 2, hal ini disebabkan pengertian-pengertian yang bersifat umum ditempatkan dalam pasal 1.

${ }_{23}^{22}$ Pasal 67 ayat 2 Konsep KUHP 2006.

${ }_{23}$ Perumusan ini mengakomodir keresahan masyarakat hukum adat selama ini yang seringkali harus berhadapan dengan korporas yang menggunakan hukum formal dalam kehidupan sehari-hari. Biasanya terjadi dalam kasus sengketa tanah adat yang dirambah. Seperti yang dialami oleh Loir Botor Dingit, Kepala Suku Dayak Bentian Jato Rempangan Jelmu Sibak, Kecamatan Bentian, Kabupaten Kutai, Kalimantan Timur yang harus menghadapi PT Kalhold Utama milik Bob Hasan yang menggusur tanah adat, tanaman dan makam leluhur Jelmu Sibak. Lihat lebih lanjut dalam Loir Botor Dingit. Kasus Sengketa Tanah Adat di Jelmu Sibak, Pertarungan Hukum Adat versus Hukum Formal dalam Sandra Kartika dan Candra Gautama. Menggugat Posisi Masyarakat Adat Terhadap Negara (Prosiding Sarasehan Masyarakat Adat Nusantara, Jakarta 15-16 Maret 1999). Yogyakarta. Pustaka Pelajar. 1999. HIm. 7.
} 
Secara adminstratif, masyarakat $\mathrm{Ba}$ duy berada di Desa Kanekes Kecamatan Leuwidamar Kabupaten Lebak Provinsi Banten. ${ }^{24}$ Kabupaten Lebak sendiri terletak di sebelah selatan Banten sehingga lazim juga disebut sebagai Banten Selatan.

Sebagaimana pernah disampaikan Marc Ancel bahwa tiap masyarakat terorganisir memiliki sistem hukum pidana yang terdiri dari: peraturan-peraturan hukum pidana dan sanksinya, prosedur hukum pidana, mekanisme pelaksanaan pidana, ${ }^{25}$ maka demikian halnya dengan masyarakat adat Baduy, mereka memiliki sistem hukum pidana tersendiri beserta tiga komponen sebagaimana disampaikan Marc Ancel.

Beberapa peraturan-peraturan hukum pidana adat Baduy yang bersifat umum bahkan telah dikenal luas seperti larangan mengambil gambar (baik foto maupun video) di wilayah Baduy Dalam, menggunakan alat mandi (sabun, sabun dll). ${ }^{26}$ Berbagai peraturan tersebut berlaku bagi warga Baduy dan wisatawan yang berkunjung ke Baduy.

Hukum pidana adat Baduy tidak banyak dikaji secara spesifik sebagai sebuah sistem hukum pidana substantif

\footnotetext{
${ }^{24}$ Dinas Informasi, Komunikasi, Seni Budaya dan Pariwisata Kabupaten Lebak. Membuka Tabir Kehidupan Tradisi Budaya Masyarakat Baduy dan Cisungsang Serta Peninggalan Sejarah Situs Lebak Sibedug. 2004. HIm.7

${ }^{25}$ Barda Nawawi Arief. Bunga Rampai Kebijakan Hukum Pidana, Perkembangan Penyusunan Konsep KUHP Baru. Jakarta. Kencana Prenada Media. 2008. HIm. 24.

${ }_{26}$ Pada dasarnya larangan yang bersifat umum tersebut telah diketahui oleh wisatawan yang berkunjung ke Baduy.
}

(dalam pengertian hukum materil, hukum formil dan hukum pelaksanaan pidana). Pada dasarnya beberapa literatur hanya menggambarkan sekilas larangan/ pantangan dalam masyarakat adat Baduy dibalik tema besar kajian budaya Baduy.

Terbatasnya pencantuman perbuatan yang dilarang/"tindak pidana" tersebut dapat dimaklumi mengingat hukum pidana adat Baduy tidak dibuat secara tertulis. Menurut Ayah Mursyid, wakil jaro (kepala kampung) Cibeo, Baduy tidak memiliki kitab mengenai laranganlarangan dalam adat Baduy. ${ }^{27}$ Namun hal ini tak berarti bahwa tetua adat Baduy dan masyarakatnya tak mengetahui larangan-larangan dalam adat Baduy. Pengetahuan mengenai larangan adat diperoleh masyarakat secara turun temurun berdasarkan budaya lisan dan kebiasaan. Perbuatan-perbuatan lainnya seperti zina, sengketa tanah, perkelahian dan perbuatan terlarang lainnya juga diatur dalam hukum pidana adat Baduy berikut prosedural persidangan, sanksi dan pelaksanaannya. Penelitian yang dilakukan ini akan lebih memfokuskan pada hukum pidana adat Baduy dalam pengertian hukum substantif adat Baduy dengan menitikberatkan kajian pada hukum pidana materil adat Baduy.

\footnotetext{
${ }^{27}$ Wawancara pra penelitian dengan Ayah Mursyid tanggal 8 Desember 2009. Dalam wawancara tersebut Ayah Mursyid menyiratkan perlunya semacam kitab yang mengatur mengenai larangan-larangan adat Baduy, sebab menurutnya selama ini hanya berdasarkan ingatan yang bisa saja ada yang terlupa saat penelitian berlangsung.
} 


\section{BAB III \\ HASIL PENELITIAN DAN PEMBAHASAN}

\section{A. Sistem Hukum Pidana Substantif Adat Baduy \\ 1. Asal Usul Baduy}

Secara geografis lokasi masyarakat Baduy terletak pada $6^{\circ} 27^{\prime} 27^{\prime \prime}-6^{\circ} 30^{\prime}$ Lintang Utara (LU) dan 108 $3^{\prime} 9^{\prime \prime}$ $106^{\circ} 4^{\prime} 55^{\prime \prime}$ Bujur Timur (BT). Masyarakat Baduy berada pada wilayah bagian barat Pulau Jawa, pada daerah yang merupakan bagian dari pegunungan Kendeng (900 mdpl). ${ }^{28}$ Secara administratif masyarakat Baduy tinggal di Desa Kanekes Kecamatan Leuwidamar Kabupaten Lebak Propinsi Banten.

Menurut Jaro Dainah, Kepala Desa Kanekes, Desa Kanekes terdiri dari 59 kampung yang terdiri dari tiga kampung Baduy Dalam, 55 kampung Baduy Luar dan satu kampung luar Baduy. ${ }^{29}$ Jumlah kampung Baduy Dalam tidak akan mengalami perubahan hingga kapanpun, selalu berjumlah tiga (Cibeo, Cikartawana, Cikeusik). Sementara jumlah kampung Baduy Luar dapat berubah sesuai dengan pemekaran wilayah. ${ }^{30}$ Satu kampung yang

\footnotetext{
${ }^{28}$ R. Cecep Eka Permana. Tata Ruang Masyarakat Baduy. Jakarta. Wedatama Widya Sastra. 2006. HIm. 17.

29 Wawancara dengan Jaro Dainah, 24-25 April 2010.

30 Pada tahun 1985 jumlah kampung di Desa Kanekes sebanyak 30 kampung. Pada 1996 meningkat menjadi 49, lalu tahun 2005 jumlah kampung di Desa Kanekes meningkat lagi menjadi 52 kampung. Lihat dalam Suhada. Masyarakat Baduy dalam Rentang Sejarah.

disebut Jaro Dainah sebagai luar Baduy adalah Cicakal Girang. Cicakal Girang tidak dikategorikan sebagai Baduy Luar karena kebanyakan warga Cicakal Girang mulai menjadi pemeluk agama Islam, sementara warga Baduy Dalam dan Baduy Luar adalah pemeluk agama sunda wiwitan.

\section{Perbedaan Baduy Dalam dan Baduy Luar.}

Baduy Dalam memiliki berbagai ciri dan aturan yang berbeda dengan Baduy Luar. Namun secara prinsipil perbedaan mereka terletak pada ketat longgarnya aturan adat yang harus mereka jalani. Masyarakat Baduy Dalam memiliki aturan adat yang lebih ketat dibandingkan masyarakat Baduy Luar. Namun demikian, dalam konsep hukum adat Baduy, keduanya memiliki perannya masingmasing. Menurut Jaro Dainah, masyarakat Baduy Dalam berkewajiban dalam hal bertapa. Tapa yang dimaksud bukan diartikan sebagai bersemedi, namun tapa dalam pengertian meneguhkan/melestarikan adat Baduy, meneguhkan agama sunda wiwitan. Sementara masyarakat Baduy Luar bertugas sebagai panamping, untuk menjaga masyarakat Baduy Dalam yang sedang bertapa, sehingga turut juga membantu meneguhkan adat.

Karena perbedaan prinsipil tersebut maka Baduy Dalam memiliki aturan yang lebih ketat dalam menjalankan hukum adat dan melestarikan adat Baduy, se-

Serang. Dinas Pendidikan Propinsi Banten. 2003. HIm.11 
mentara Baduy Luar memiliki aturan yang lebih longgar namun memiliki konsekwensi untuk turut membantu Baduy Dalam dalam hal melestarikan adat.

Pada prinsipnya larangan-larangan pada masyarakat Baduy dilandaskan pada filosofi dasar Baduy, lojor teu meunang dipotong, pondok teu meunang disambung (panjang tak boleh dipotong, pendek tak boleh disambung). Menurut Jaro Dainah, konsep dasar ajaran di Baduy tersebut adalah keseimbangan alam, kelestarian alam, maka dengan demikian Baduy mempunyai kewajiban untuk melestarikan alam dan tidak menentang hukum alam.

Skema 3: Alur penyelesaian perkara dalam Hukum Pidana Adat Baduy

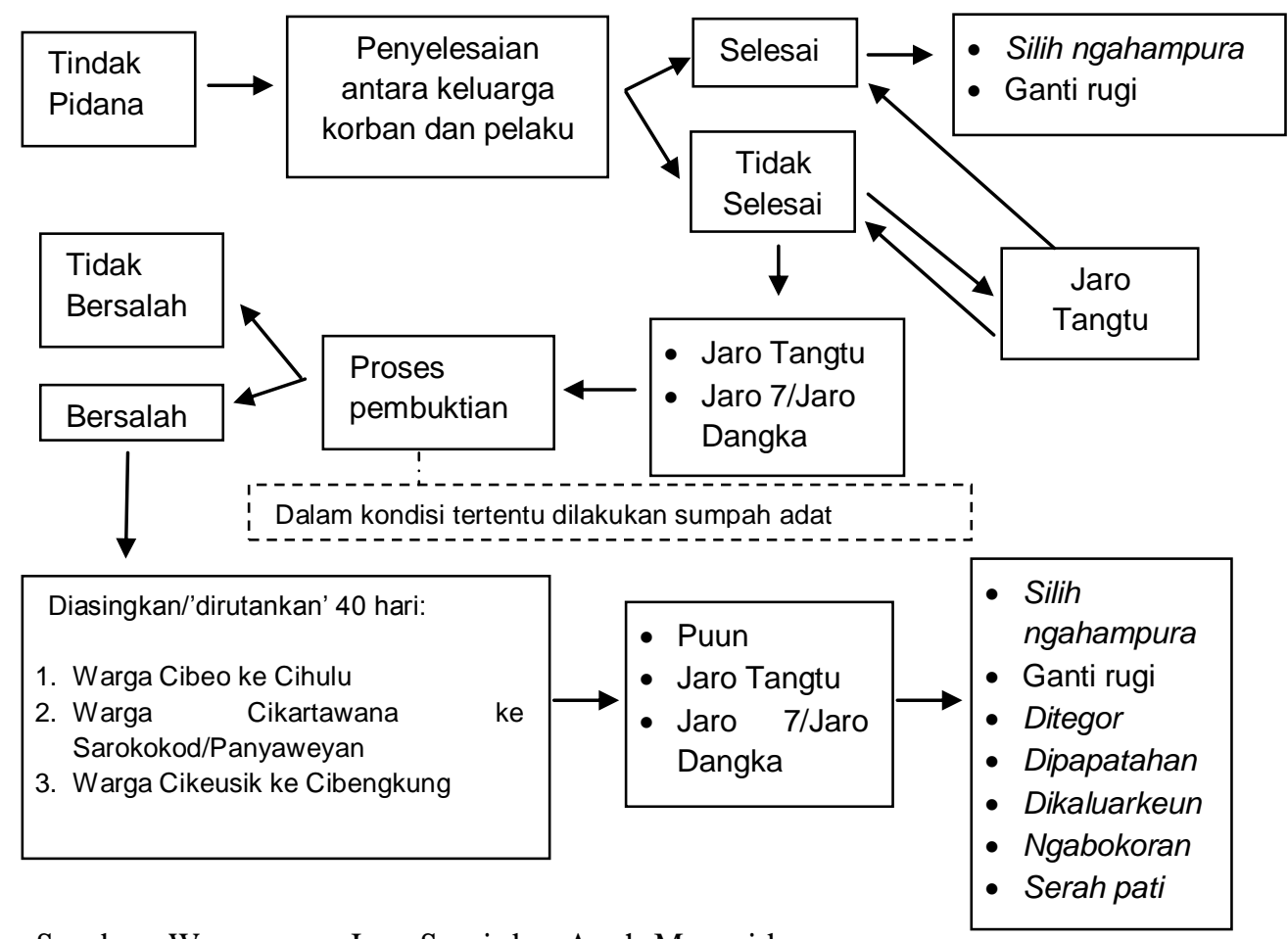

Sumber: Wawancara Jaro Sami dan Ayah Mursyid

\section{Hukum Pidana Formil Adat Baduy}

Hukum Pidana Adat Baduy mengenal semacam asas ultimum remedium atau asas subsidiaritas. Hukum pidana formal adat Baduy menerapkan asas ultimum remedium sehingga sistem peradilan pidana adat Baduy baru dipakai jika penyelesaian perkara tingkat keluarga para pihak (pelaku dan korban) tidak berjalan. Tahap awal selalu diusahakan diselesaikan di pihak keluarga. Secara skematik prosedur penyelesaian tindak pidana dalam hukum pidana adat Baduy dapat digambarkan sebagai berikut : 
Skema di atas dibedakan pula berdasarkan berat dan ringannya perbuatan. Terhadap perbuatan yang berat semisal pembunuhan maka penyelesaian di

'Dirutankan' dalam skema tersebut mengandung pengertian yang berbeda dengan rumah tahanan sebagaimana dikenal dalam hukum acara pidana. Meskipun demikian keduanya memiliki kesamaan yakni menunggu persidangan hingga penghukuman yang harus diterima pelaku. 'Rutan' adalah istilah Baduy yang mucul belakangan sebagai tempat dimana si pelaku harus dikeluarkan selama empat puluh hari sambil menunggu persidangan. Istilah rutan tersebut jelas diintrodusir dari rutan (rumah tahanan) dalam terminologi hukum acara pidana. Dalam masa menunggu sidang tersebut si pelaku oleh Jaro Dangka/Jaro 7 ditempatkan di kampung yang disesuaikan dengan jalur 'rumah tahanannya' (sebagaimana tertera dalam skema).

Menurut Jaro Sami, dalam masa penahanan selama 40 hari tersebut, si pelaku yang berada dalam masa pengawasan Jaro Dangka ditempatkan dalam sebuah rumah yang ditentukan oleh Jaro Dangka. Pelaku kemudian melakukan semacam kerja sosial mencari kayu bakar, atau mengambil air tanpa diupah. Jika kemudian si pelaku lari maka Jaro Dangka/Jaro 7 yang bertanggungjawab mencari. Masa karantina selama 40 hari tersebut mengandung pembinaan mental si pelaku. tingkat keluarga dapat dilangkahi langsung menuju penyelesaian oleh Jaro Tangtu dan Jaro 7/Jaro Dangka.

\section{Hukum Pidana Materil Adat Baduy}

Sebagaimana umumnya sebuah komunitas masyarakat, masyarakat Baduy memiliki sistem hukum yang mengatur kehidupan mereka sehari-hari, termasuk di dalamnya hukum pidana adat Baduy.

Hukum pidana adat Baduy tidak dikodifikasikan dalam sebuah kitab, hukum pidana adat Baduy tidak dibuat tertulis. Menurut Jaro Sami, untuk melestarikan pengetahuan hukum pidana adat Baduy tersebut maka setiap dua bulan sekali semua warga dikumpulkan di lapangan di masing-masing kampung Baduy Dalam (Cibeo, Cikartawana, Cikeusik). Dalam forum tersebut diberitahukan setiap larangan yang ada di Baduy beserta ancaman hukumannya. Selain forum tersebut, pengetahuan mengenai hukum pidana adat Baduy diperoleh melalui budaya lisan/tutur dalam kehidupan sehari-hari, sehingga setiap generasi di Baduy mengenal akan hukumnya.

Sebagaimana halnya adat Baduy, hukum pidana adat Baduy juga berfilosofi pada keseimbangan alam, filosofi yang dipakaipun sama, lojor teu meunang dipotong, pondok teu meunang disambung (panjang tak boleh dipotong, pendek tak boleh disambung). Falsafah hidup tersebut kemudian dijabarkan dalam norma- 
norma hukum di Baduy, termasuk norma hukum pidana adat Baduy.

Pada prinsipnya dalam hukum pidana adat Baduy, seorang pelaku tindak pidana harus dibersihkan lahir dan batinnya. Pembersihan tersebut merupakan wujud dari pertanggungjawaban pelaku tindak pidana. Pembersihan lahiriah berupa pertanggungjawaban pelaku pada korban yang mewujud dalam sanksi yang diterimanya. Sanksi tersebut berupa ditegor/ditegur, dipapatahan/dinasehati, silih ngahampura, ganti rugi, hingga dikeluarkan dari warga Baduy Dalam menjadi warga Baduy Luar.
Pembersihan batiniah si pelaku diwujudkan dalam upacara ngabokoran atau serah pati. Ngabokoran adalah upacara pembersihan batiniah atas tindak pidana yang tidak terlalu berat. Serah pati adalah upacara pembersihan batiniah atas tindak pidana berat. Ngabokoran dan serah pati secara integral juga merupakan pembersihan desa atas tindak pidana yang telah terjadi dengan memohonkan maaf pada leluhur yang dipimpin oleh puun. Untuk lebih jelasnya penjelasaan di atas dapat digambarkan dalam skema berikut ini:

Skema 4: Konsep Bentuk Pertanggungjawaban dalam Hukum Pidana Adat Baduy

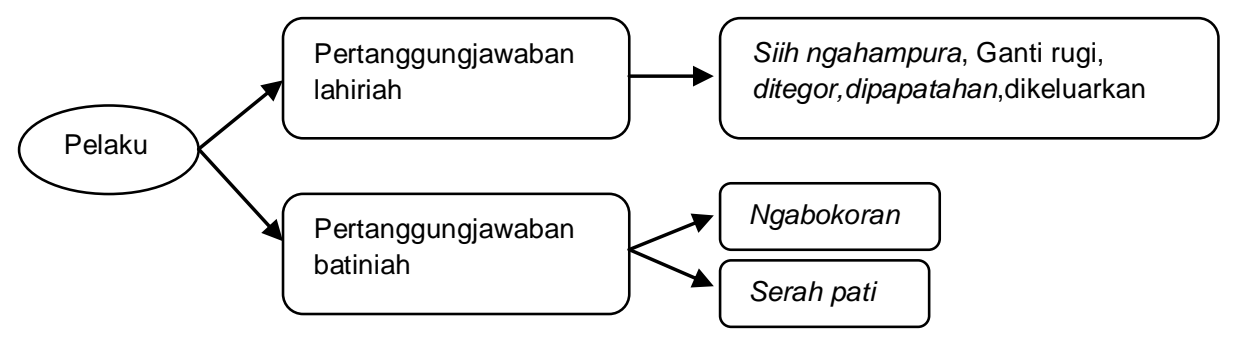

Sumber: Wawancara Jaro Sami, Ayah Mursyid, dan Jaro Dainah.

Dalam upacara ngabokoran beberapa bahan untuk ngabokoran disediakan oleh keluarga pelaku diantaranya perangkat sepaheun: sereh, gambir, pinang. Jika si pelaku sudah meninggal namun belum sempat ngabokoran, maka bahan ngabokoran ditambahkan dengan menyan.

Dalam upacara serah pati pada prinsipnya sama dengan ngabokoran, memohon maaf pada leluhur karena si pelaku dan desa telah tercemar dengan tindak pidana. Namun upacara serah pati dilakukan atas tindak pidana yang dianggap berat misalnya pembunuhan, sebab dalam pembunuhan si pelaku telah menghilangkan nyawa/ngalengitkeun jiwa yang merupakan hak yang maha kuasa. 
1) Aturan Umum dalam Hukum Pidana Adat Baduy

Dari penelitian yang dilakukan oleh peneliti didapatkan berbagai aturan umum mengenai hukum pidana substansi adat Baduy sebagai berikut:

\section{a. Asas Ultimum Remedium}

Baduy mengenal asas yang identik dengan asas ultimum remedium dan diterapkan integral dalam penyelesaian tindak pidana. Artinya jika ada suatu tindak pidana, maka penyelesaian dalam tahap keluarga sedapat mungkin dilakukan. Jika para pihak tidak puas barulah kemudian diserahkan pada sistem peradilan adat Baduy. Adanya asas ultimum remedium di Baduy terungkap dalam jawaban Ayah Mursid dalam menjelaskan proses penyelesaian tindak pidana di Baduy sebagai berikut : ${ }^{31}$

Dasarna musyawarah, rembugan keluarga, silih ngahampura. Lamun teu puas diteruskeun $k a$ kokolot lembur, lamun teu puas diteruskeun ka jaro tujuh, lamun teu puas terus $k a$ desa (Dasarnya musyawarah, rembugan keluarga, saling memaafkan. Kalau tidak puas diteruskan ke sesepuh desa, kalau tidak puas diteruskan ke jaro tujuh, kalau tidak puas diteruskan ke desa).

\section{b. Musyawarah}

Menurut Ayah Mursyid, dasar dari penyelesaian tindak pidana di Baduy adalah musyawarah/ dasarna musya-

\footnotetext{
${ }^{31}$ Wawancara dengan Ayah Mursyid di Cibeo tanggal 24 April 2010.
}

warah. Apa yang diinginkan oleh si korban dan keluarganya yang sekiranya dapat memulihkan kondisi korban atas tindak pidana yang telah terjadi, demikian halnya dengan pelaku, apa yang dapat dilakukan agar si pelaku dan keluarganya dapat terbebas dari perasaan bersalah dan menyelesaikan tindak pidana yang telah dilakukan. Jika kemudian tindak pidana tersebut menimbulkan keguncangan yang mengganggu keseimbangan masyarakat maka harus diadakan upacara ngabokoran agar keseimbangan kampung kembali pulih.

Konsep musyawarah dalam penyelesaian perkara pidana tersebut pada dasarnya memiliki kesamaan dengan model restorative justice dalam menyelesaikan perkara pidana. Dalam pelajaran audio visualnya, John Braithwaite menjelaskan konsep restorative justice sebagai berikut: ${ }^{32}$

Restorative Justice adalah cara yang lebih produktif dalam menangani kejahatan dibandingkan dengan memasukan orang lagi dan lagi ke dalam penjara. Ide utamanya adalah memulihkan korban, memulihkan pelaku dan memulihkan masyarakat (community), keadilan harus dipulihkan. Dalam restorative justice pihak korban dan pihak pelaku difasilitasi duduk bersama dalam lingkaran. Pertama membicarakan tentang apa yang telah

32

http://www.anu.edu.au/fellows/jbraithwaite/le ctures/index.php 
terjadi, siapa yang telah disakiti/dirugikan dari kejadian tersebut, dan apa kiranya yang dapat dilakukan untuk memperbaiki keadaan yang ditimbulkan dari suatu kejadian beserta diikuti oleh rencana aksinya. Kita (mediator) menindaklanjuti dengan memeriksa rencana aksi untuk dapat diterapkan untuk kepuasan semua pihak terkait (stakeholders).

\section{c. Asas Personalitas/Nasional Aktif ${ }^{33}$}

Penerapan asas personalitas pernah terjadi di Baduy pada pertengahan Agustus di tahun 2005. Saat itu Sadim seorang warga Cikeusik Baduy Dalam, melakukan pembunuhan atas Kamsina dan melukai Yadi dan Aisah. Peristiwa tersebut terjadi di Kampung Citebang Desa Sukajaya Kecamatan Sobang Kabupaten Lebak. Tempat terjadinya tindak pidana (locus delicti) tersebut berada di luar wilayah Baduy Dalam, namun Sadim tetap dimintakan pertanggungjawaban dan diadili dengan menggunakan hukum pidana adat Baduy setelah divonis penjara 7 bulan 8 hari oleh Pengadilan Negeri Rangkasbitung yang didasarkan pada dakwaan pasal 351 ayat 3 (penganiayaan yang mengakibatkan kematian). ${ }^{34}$

\footnotetext{
${ }^{33}$ Asas ini juga dikenal sebagai asas kebangasaan/nationaliteits beginsel/personaliteits beginsel/actieve persoonlijkheidsstelsel/actieve nationaliteits beginsel lihat dalam PAF Lamintang. Dasardasar Hukum Pidana Indonesia. Bandung. Sinar Baru. 1984. HIm 85.

${ }^{34}$ Lihat lebih lanjut dalam lampiran mengenai kronologis perkara Sadim bin Samin dan
}

Menurut Ayah Mursyid, hukum pidana adat Baduy Dalam berlaku bagi setiap warga Baduy Dalam. Jika seorang Baduy Dalam diketahui melakukan pelanggaran di luar wilayah Baduy Dalam misalnya menaiki kendaraan, mencuri dan sebagainya maka perbuatan tersebut harus dipertanggungjawabkan dalam proses persidangan Baduy Dalam. Bahwa kemudian ada persoalan ne bis in idem karena telah diproses menurut hukum negara, maka hal itu diabaikan karena masyarakat Baduy telah memiliki sistem hukum tersendiri yang pada hakikatnya si pelaku harus dibersihkan lahir dan batinnya untuk memulihkan keseimbangan dalam masyarakat Baduy.

Ketentuan asas personalitas pada Baduy Dalam juga berlaku bagi warga Baduy Luar. Bagi warga Baduy Luar yang melakukan tindak pidana di luar wilayah Baduy Luar diserahkan pada Jaro Dainah, Kepala Desa Kanekes, kebanyakan kemudian diserahkan pada hukum pidana nasional, namun dalam hal pembersihan batinnya diserahkan pada struktur adat Baduy Dalam.

\section{d. Asas Perlindungan/ Nasional Pasif $^{35}$}

Dalam hukum pidana adat Baduy, kepentingan adat Baduy juga mendapatkan

\begin{tabular}{l}
\hline Putusan PN Rangkasbitung \\
210/PidB/2005/PNRKB. \\
${ }^{35}$ Nama lain asas ini beschermingsbeginsel/ \\
passief nationaliteitsbeginsel/realprinzip/ \\
schutzprinzip/ prinzip der beteiligten \\
rechtsordnung. PAF Lamintang. Dasar-dasar \\
Hukum Pidana Indonesia. Bandung. Sinar Baru. \\
1984. HIm 85.
\end{tabular}


Jurnal Law reform April 2010. Vol. 5. No.1

perlidungan, sehingga bagi siapapun yang merugikan kepentingan hukum adat Baduy harus dimintakan pertanggungjawaban. Penerapan asas ini pernah terjadi saat stasiun televisi swasta Trans TV membuat liputan mengenai Baduy. Sebagaimana diketahui, di wilayah Baduy Dalam (Cibeo, Cikartawana, Cikeusik) terlarang untuk dipublikasikan, baik berupa foto maupun gambar audio visual. Kru Trans TV dengan diam-diam mengambil gambar di wilayah Baduy Dalam, kemudian disiarkan dalam sebuah acara peliputan. Penyiaran wilayah Baduy Dalam ini kemudian diketahui luas hingga ke masyarakat Baduy Dalam sendiri. Penyiaran tersebut segera menuai protes yang meluas hingga akhirnya pihak Trans TV datang meminta maaf dimediatori Taufikurahman Ruki, mantan Ketua KPK (Komisi Pemberantasan Korupsi) yang merupakan tokoh masyarakat Kabupaten Lebak. ${ }^{36}$ Menurut Jaro Sami, paska kejadian tersebut mereka harus ngabokoran yang merupakan upacara adat untuk meminta maaf pada leluhur (karuhun), pembersihan, agar keseimbangan kembali terjaga.

Asas perlindungan dalam KUHP diatur dalam Pasal 4 dan Pasal 8. Kepentingan hukum negara yang diatur dalam pasal ini meliputi: ${ }^{37}$

\footnotetext{
${ }^{36}$ Wawancara dengan Suhada, Jaro Dainah dan Jaro Sami.

37 PAF Lamintang. Dasar-dasar Hukum Pidana Indonesia. Bandung. Sinar baru. 1984.HIm.105.

a. Terjaminnya keamanan negara dan keselamatan serta martabat kepala negara dan wakilnya.

b. Terjaminnya kepercayaan terhadap mata uang, materai-materai, dan merek-merek yang telah dikeluarkan oleh pemerintah Indonesia

c. Terjaminnya kepercayaan terhadap surat-surat atau sertifikatsertifikat utang yang telah dikeluarkan oleh pemerintah Indonesia

d. Terjaminnya alat-alat pelayaran Indonesia terhadap kemungkinan dibawa ke dalam kekuasaan-kekuasaan bajak laut.

\section{e. Asas Teritorial}

Andi Hamzah mengemukakan bahwa landasan asas teritorial adalah kedaulatan negara di wilayahnya sendiri. Bertitik tolak dari landasan tersebut, maka hukum pidana berlaku bagi siapapun juga yang melakukan delik di wilayah negara tersebut. ${ }^{38}$ Pada prinsipnya hukum pidana adat Baduy menganut pula asas teritorial, namun demikian, keberlakuannya tidak penuh pada setiap delik dalam hukum pidana adat Baduy. Dengan demikian hukum pidana adat Baduy dapat dikatakan menganut asas teritorial yang bersifat quasi. Keberlakuan asas teritorial bagi warga di luar Baduy hanya pada delikdelik yang bersifat umum berlaku bagi

\footnotetext{
${ }^{38}$ Andi Hamzah. Asas-asas Hukum Pidana.Jakarta. Rineka Cipta. 1994.HIm.64.
} 
masyarakat Baduy seperti penganiayaan, yang berdiri sendiri yang tidak ada mencuri, penipuan, mengambil foto, hubungannya satu sama lain. Hal ini juga menggunakan alat mandi seperti sabun, shampo dan sebagainya. Sementara terhadap delik yang bersifat lebih khusus seperti larangan mengenakan pakaian modern, alat elektronik dan sebagainya hanya berlaku bagi warga Baduy Dalam. Larangan tersebut diberlakukan pada warga Baduy Dalam namun tidak diberlakukan pada warga luar Baduy. Bagi para pelanggarnya dikenakan sanksi yang berjenjang mulai sanksi verbal (ditegur, dinasehati/ dipapatahan) hingga dikeluarkan dari komunitas Baduy Dalam

\section{2) Bentuk-Bentuk Tindak Pidana \\ a. Perbarengan}

J.E.Jonkers menjelaskan concurcus idealis (kebersamaan dalam peraturan) terjadi apabila suatu peristiwa pidana terkena oleh lebih dari satu peraturan pidana, maka hanya diperlakukan salah satu peraturan pidana, yaitu yang menentukan hukuman pokok yang paling berat. ${ }^{39}$ Sistem penjatuhan pidana ini oleh Jonkers disebut sebagai sistem absorbsi (peraturan yang paling berat menutupi yang lebih ringan). ${ }^{40}$ Dalam KUHP concursus idealis diatur dengan Pasal 63. Menurut Jonkers, beberapa peraturan yang terkena pada sebuah peristiwa tersebut haruslah peristiwa yang berhubungan satu sama lain, bukan peristiwa

\footnotetext{
39 J.E.Jonkers. Buku Pedoman Hukum Pidana Hindia Belanda. Jakarta. Bina Aksara. 1987. HIm.207

${ }^{40}$ Ibid. HIm. 206.
} berlaku pada satu peristiwa yang menimbulkan dua akibat seperti tabrakan karena sebuah kelalaian yang mengakibatkan kematian (Pasal 359 KUHP) dan luka badan (Pasal 360 KUHP). ${ }^{41}$

Syarat yang harus diperhatikan dalam perbuatan berlanjut adalah: (1) harus ada kesatuan kehendak peristiwa-peristiwa yang disebabkan oleh putusan kehendak yang sama; (2) peristiwa-peristiwa harus sama atau serupa; (3) jangka waktu yang ada antara berbagai bagian (perbuatan berlanjut) tidak boleh terlalu lama. ${ }^{42}$

Selain kedua hal di atas (concursus idealis dan perbuatan berlanjut), KUHP juga mengenal concursus realis (perbarengan perbuatan). ${ }^{43}$ Konsep concursus realis adalah adanya perbarengan beberapa perbuatan yang harus dipandang sebagai perbuatan yang berdiri sendirisendiri sehingga merupakan beberapa kejahatan. Terhadapnya dijatuhi satu pidana jika diancam dengan pidana pokok sejenis yang merupakan jumlah maksimum pidana yang diancamkan terhadap perbuatan itu dengan catatan tidak melebihi dari maksimum pidana yang terberat ditambah sepertiga. ${ }^{44}$ Jika perbarengan tersebut diancam dengan pidana pokok yang tidak sejenis, maka dijatuhi pidana

\footnotetext{
41 Ibid. HIm. 208

42 Ibid. HIm. 219-221.

${ }_{43}^{43}$ Pasal 65 KUHP

44 Pasal 65 ayat 2 KUHP. Sistem pemidanaan ini dinamakan sistem absorbsi yang dipertajam, peraturan pidana yang paling berat yang dijalankan ditambahi (diperberat) sepertiga diatas hukuman yang seberat-beratnya.
} 
Jurnal Law reform April 2010. Vol.5. No.1

atas tiap-tiap kejahatan tetapi jumlahnya tidak boleh melebihi maksimum pidana terberat ditambah sepertiga.

\section{b. Percobaan}

Niat dalam hukum pidana adat Baduy adalah sesuatu yang harus dipertanggunjawabkan. Sehingga jika ada seseorang yang telah berniat mencuri maka niat yang telah ada menjadi penilaian tersendiri mengingat niat tersebut tidak baik. Maka dalam hukum pidana adat Baduy tidak dipandang apakah suatu tindak pidana selesai atau tidak selesai dilakukan. Ayah Mursyid menjelaskan bahwa misalnya dalam hal pembunuhan, karena niatnya sudah tidak baik, tidak dipisahkan meninggal atau tidak meninggalnya seseorang (niatna geus teu hade, teu dipisahkeun paeh teu paeh, jelasna kudu diberikeun sanksi, geus mungkar). Hukum pidana adat Baduy dalam hal ini terfokus pada niat yang tidak baik yang harus dibersihkan, harus diberi sanksi, bahwa kemudian menim- bulkan kematian sesuai dengan niatnya maka itu hal yang lain lagi. Jika kemudian deliknya selesai berakhir pada tujuan yakni kematian, maka pertanggungjawabannya disesuaikan dengan aturan mengenai pembunuhan. Namun jika tidak selesai, niatnya tersebut telah menjadi sesuatu hal yang luar biasa dalam masyarakat Baduy, harus diwaspadai diselidiki kenapa bisa timbul niat tersebut.

\section{c. Pengulangan}

Dalam hukum pidana adat Baduy tidak dikenal adanya pemberatan hukuman terhadap pengulangan tindak pidana (residivisme) sebagaimana dalam KUHP. Namun terhadap pelaku tindak pidana yang melakukan pengulangan tin-dak pidana, maka proses penyelesaiannya ditingkatkan satu tingkatan setiap terjadi pengulangan.

Secara skematik, tahap penyelesaian tindak pidana dalam hal pengulangan dapat dilihat sebagai berikut:

Skema 5: Alur penyelesaian bentuk tindak pidana pengulangan

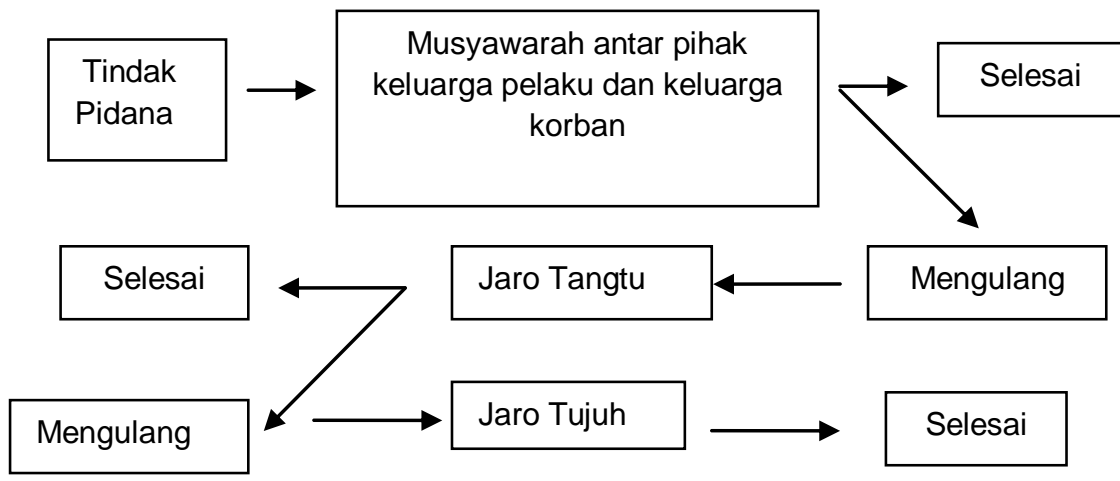

Sumber: Wawancara Ayah Mursyid 


\section{d. Penyertaan}

Dalam hukum pidana adat Baduy, tidak dibedakan bobot hukuman peran dalam suatu tindak pidana. Maka pelaku (dader); penyuruh (doenpleger); turut serta melakukan (mededader/ medepleger); pembujuk (uitlokker); dan pembantu (medeplichtige) ${ }^{45}$ tidak dibedakan dalam hal bobot hukumannya. Namun berbagai peran sebagaimana di atas juga dikenal dalam hukum pidana adat Baduy hanya sekadar membedakan peran yang dilakukan dalam suatu tindak pidana tetapi hukumannya disamaratakan sesuai dengan tindak pidana yang dituju. Mengenai hal ini Ayah Mursyid menuturkan sebagai berikut:

Sama, di kami semua yang turut serta dalam kejahatan juga ada, misalnya si pelaku ada yang nitah (menyuruh), titahan saha (suruhan siapa)? sakabehna hatena geus teu endah (semuanya hatinya/niatnya sudah tidak bagus).

Dalam Hukum pidana adat Baduy niat merupakan cerminan perilaku hati, maka semua yang terkait dengan suatu tindak pidana harus bertanggungjawab dan dibersihkan lahir dan batinnya.

\section{e. Permufakatan Jahat}

Permufakatan jahat dalam KUHP dijelaskan dalam Bab IX Pasal 88 . Permufakatan jahat dikatakan ada jika dua orang atau lebih telah sepakat akan

\footnotetext{
45 Lihat lebih lanjut konsep penyertaan dalam Topo Santoso. Menggagas Hukum Pidana Islam, Penerapan Syariat Islam dalam Konteks Modernitas. Bandung. Assyamil.2000.HIm. 156.
}

melakukan kejahatan. Sama halnya dengan $\mathrm{KUHP}^{46}$ dalam hukum pidana adat Baduy permufakatan jahat adalah bentuk tindak pidana yang harus dimintakan pertanggungjawabannya sekiranya permufakatan jahat tersebut diketahui. Menurut Ayah Mursyid, sekalipun tindak pidananya tidak jadi dilakukan karena salah seorang ataupun semuanya menarik diri namun jika diketahui ada permufakatan jahat maka semua pelaku yang telah berniat melakukan kejahatan tersebut dimintakan pertanggung-jawabannya. Sebab niatnya sudah tidak baik, maka si pelaku akan dipanggil ditelusuri kenapa punya niat yang tidak baik terhadap seseorang. Hukum pidana adat Baduy diorientasikan pada penyelesaian perkara secara tuntas, sehingga jika ada dua orang atau lebih yang berniat jahat pada seseorang diselesaikan hingga tercapai silih ngahampura, sekiranya terdapat motif dendam pada calon korban. Niat awal yang telah ada dalam hukum pidana adat Baduy dilihat sebagai potensi tindak pidana yang harus dibersihkan/ diselesaikan.

\section{3) Dasar-dasar Penghapus Pidana.}

KUHP merumuskan dasar-dasar penghapusan pidana dalam ketentuan Pasal 44 KUHP (gangguan psikis), Pasal

\footnotetext{
46 Dalam KUHP ancaman hukuman dalam permufakatan jahat tidak diatur dalam aturan umum (buku I), tetapi tersebar dalam buku II (kejahatan) misalnya dalam Pasal 125 (permufakatan jahat dalam memberikan bantuan kepada musuh pada masa perang), dan Pasal 139c (permufakatan jahat terhadap kejahatan makar).
} 
Jurnal Law reform April 2010. Vol.5. No.1

45 (belum cukup umur/minderjaring), Pasal 48 KUHP (daya paksa/overmacht), Pasal 49 KUHP (bela paksa/noodweer), Pasal 50 KUHP (kewajiban undangundang), Pasal 51 (perintah jabatan). ${ }^{47}$

\section{a. Gangguan psikis.}

Gangguan psikis di Baduy tidak dikategorikan sebagaimana di KUHP (jiwanya cacat dalam tumbuhnya/ gebrekkige ontwikkeling, dan terganggu karena penyakit/ziekelijke storing), secara sederhana mereka menamakan gangguan psikis sebagai edan/gila. Dalam hukum pidana adat Baduy, orang gila yang melakukan tindak pidana tidak dapat dimintakan pertanggungjawaban. Namun demikian bukan berarti pertanggungjawaban pidana menjadi tidak ada. Pertanggungjawaban atas tindak pidana yang dilakukan orang gila tersebut kemudian dialihkan kepada keluarganya, dengan demikian korban tetap mendapatkan hak pemulihan atau ganti rugi atas tindak pidana yang telah dialaminya. Menurut Ayah Mursyid, ketentuan pengalihan pertanggung-jawaban tersebut harus melalui persyaratan penyelidikan dan pembuktian bahwa pelaku tersebut benar-benar edan bukan hanya pura-pura untuk menghindari hukuman.

\section{b. Belum cukup umur.}

\footnotetext{
${ }^{47}$ Jan Remmelink. Hukum Pidana, Komentar atas Pasal-Pasal Terpenting dari Kitab UndangUndang Hukum Pidana Belanda dan Padanannya dalam Kitab Undang-Undang Hukum Pidana Indonesia. Jakarta. Gramedia Pustaka Utama. 2003. HIm.202.
}

Pelaku tindak pidana yang belum cukup umur $^{48}$ dalam hukum pidana adat Baduy dipertimbangkan untuk tidak dipidana. Umumnya terhadap pelaku tersebut dikembalikan pada orang tuanya kecuali jika orang tuanya menyerah, tidak sanggup untuk mendidik anak tersebut dan diserahkan ke hukum pidana adat Baduy. Sama halnya dengan pelaku yang gila, akibat yang timbul dari tindak pidana dialihkan kepada orang tua untuk diselesaikan. Hal yang perlu diperhatikan dari tindak pidana yang dilakukan kedua jenis pelaku diatas (gila dan belum cukup umur) adalah bahwa perbuatannya tetap merupakan tindak pidana tetapi karena terdapat semacam alasan pemaaf maka pembuat tindak pidana tidak dipidana.

Dalam konteks tersebut di atas terdapat persamaan dan perbedaan antara hukum pidana adat Baduy dan KUHP. Persamaannya terletak pada adanya alasan pemaaf dan adanya tindakan (dikembalikan pada orang tua atau adat/negara untuk dibina). Pada dasarnya upaya ini merupakan bagian dari kebijakan perlindungan masyarakat (social defence policy). Perbedaannya kemudian terletak pada pertanggung jawaban atas tindak pidana yang terjadi. Hukum pidana adat Baduy menyadari bahwa keseimbangan telah terganggu dengan adanya suatu tindak pidana, ada korban yang timbul akibat suatu tindak pidana sehingga keseimbangan tersebut harus di-

\footnotetext{
${ }^{48}$ Batas usia pertanggungjawaban anak di Baduy adalah di atas 10 tahun, wawancara dengan Jaro Dainah tanggal 25 April 2010.
} 
pulihkan kembali. Maka pertanggungjawaban tersebut kemudian dialihkan pada orang tua untuk memulihkan keseimbangan yang telah terusik. Pada KUHP pertanggungjawaban pidana atas tindak pidana yang dilakukan orang gila atau orang yang belum cukup umur dihapuskan, hal ini disebabkan karena orientasi hukum pidana lebih terarah pada pelaku (offender oriented), korban bukan merupakan bagian integral penyelesaian perkara dalam KUHP.

\section{c. Pembelaan Terpaksa.}

Hukum pidana adat Baduy mengenal pengaturan mengenai pembelaan terpaksa (noodwer) sebagaimana dikenal dalam KUHP. Kesamaan adanya pengaturan mengenai pembelaan terpaksa tersebut juga termasuk mengenai pembelaan terpaksa yang melampaui batas (noodweer exces). ${ }^{49}$ Meskipun kedua aturan tersebut juga ada dalam hukum pidana adat Baduy, namun terdapat perbedaan dalam pelaksanaannya. Jika dalam pembelaan terpaksa yang melampaui batas tersebut kemudian mengakibatkan kematian pada si pelaku (pada awalnya) yang kemudian menjadi korban, maka meskipun orang yang melakukan pembelaan terpaksa yang melampaui batas tersebut tidak dipidana karena terdapat alasan pemaaf, tetapi ia tetap harus dibersihkan batinnya karena

\footnotetext{
${ }^{49}$ Noodwer merupakan alasan pembenar (faits justificatifs) sementara noodweer'exces merupakan alasan pemaaf (faits d'excuse).Lebih lanjut mengenai ketentuan ini lihat dalam Ch.J.Enschede dan A. Heijder (terjemahan R Achmad Soema di Pradja). AsasAsas Hukum Pidana. Bandung. Almuni. 1982. HIm. 249.
}

telah ngalengitkeun jiwa (menghilangkan nyawa) dengan cara diadakan upacara serah pati.

\section{4) Kualifikasi Tindak Pidana ${ }^{50}$}

Hukum Pidana Adat Baduy tidak menamakan dan memisahkan secara tegas antara kejahatan dan pelanggaran. Namun jika perbedaan diatas didasarkan pada persoalan berat dan ringannya perbuatan, maka hukum pidana adat Baduypun mengenal tindak pidana berdasarkan berat dan ringannya perbuatan. Untuk tindak pidana yang bersifat berat maka pembesihan batinnya menggunakan serah pati, sedangkan untuk tindak pidana yang bersifat ringan pembersihan batinnya menggunakan ngabokoran. Kendati demikian tidak ada pemisahan tegas mana yang merupakan tindak pidana ringan dan tindak pidana berat, ukuran berat ringannya perbuatan nampaknya didasarkan pada seberapa besar tindak pidana tersebut mengguncangkan perasan kemanusiaan dan masyarakat Baduy (Shocking to the conscience of humanity and Baduy community). Adapun berbagai tindak pidana yang diatur dalam hukum pidana Baduy adalah sebagai berikut

\footnotetext{
${ }^{50}$ Disarikan dari wawancara dengan Jaro Dainah dan Jaro Sami tanggal 25 April 2010, Ayah Mursyid tanggal 8 Desember 2009 dan 24 April 2010, Haji Sapin dan Sarpin tanggal 8 Desember 2009, Aman Sukarso 23 Juli 2009, Devi Naufal Michrob medio 2009, Firman Venayaksa medio 2009, Suhada akhir 2009. Saidam, 24 April-10 Juni 2010. Abdul Hamid medio 2009. Asep tanggal 7 Juni 2010.
} 


\section{a. Fitnah/Pencemaran Nama Baik.}

Derajat tindak pidana fitnah dalam hukum pidana adat Baduy dibedakan pada sasaran fitnah. Fitnah terhadap pejabat adat derajatnya lebih tinggi dibandingkan fitnah pada warga Baduy biasa. Hal ini menurut Ayah Mursyid disebabkan karena pejabat adat sebagai pimpinan harus dihargai bersama, maka jika ada orang yang tidak menghargai pimpinan dibedakan dengan fitnah pada orang biasa. Fitnah pada orang biasa dapat diselesaikan antara pihak keluarga, sementara fitnah terhadap pimpinan harus diselesaikan secara adat (sistem peradilan adat Baduy) karena pimpinan adat merupakan simbol adat.

\section{b. Zina}

Zina dalam Baduy dibedakan penanganannya, persidangan untuk perkara zina tidak segera dilangsungkan sebagaimana seharusnya sesuai hukum pidana formal adat Baduy. Pelaku segera dikirimkan ke 'rutan' selama 40 hari, proses persidangan baru dilakukan setelah masa karantina selesai. Hal ini disebabkan zina dianggap aib yang memalukan semua pihak, baik korban, pelaku maupun masyarakat Baduy.

Zina juga dibedakan bobotnya antara suka sama suka tanpa ada perikatan pernikahan, dengan zina yang melibatkan hak batur/hak orang lain, misalnya berhubungan badan dengan pacar atau istri orang lain. Bobot hukuman terhadap jenis zina yang terakhir lebih berat dari jenis yang pertama.

\section{c. Perkosaan}

Perkosaan dalam hukum pidana adat Baduy merupakan bagian dari zina. Tetapi perbedaan utama dari perkosaan adalah dilakukan dengan paksaan, tidak didasari suka sama suka. Terhadap tindak pidana semacam ini, maka umumnya dinikahkan jika pihak korban menghendaki, namun jika tidak, pada umumnya pelaku dikenai sanksi dikeluarkan dari Baduy Dalam.

\section{d. Pencurian}

Sebagaimana ditulis sebelumnya, hukum pidana adat Baduy memandang korban sebagai bagian integral dari sistem penyelesaian perkara pidana. Maka dalam tindak pidana pencurian, pelaku pencurian diwajibkan mengganti kerugian pihak korban dan silih ngahampura. Jika pelaku meninggal sebelum ganti rugi terjadi, maka ganti rugi diserahkan pada sabah (keluarga bapak/ibunya). Pelaku juga akan ditanya kesanggupan untuk tidak mengulangi perbuatan, jika tidak sanggup maka ia akan dikeluarkan dari Baduy Dalam. Dalam tindak pidana pencurian pelaku diwajibkan membiayai upacara ngabo-koran.

\section{e. Penipuan}

Proses penegakan hukum pidana adat Baduy dalam hal penipuan bermula dari adanya pengaduan dari korban. Namun hal ini tidak diartikan penipuan sebagai delik aduan (klacht delicten). Adanya pengaduan korban lebih merupakan perwujudan dari asas ultimum remedium manakala si pelaku tidak mau ber- 
tanggungjawab atau tidak menemukan kesepakatan dalam hal ganti rugi sehingga penyelesaian pada tahap keluarga tidak tercapai.

Dalam tindak pidana penipuan, pada prinsipnya pertanggungjawaban pidana lebih diarahkan pada ganti rugi. Biasanya pelaku diminta membuat perjanjian untuk mengganti rugi, jika pelaku tak punya uang maka harus menjual hartanya (misalnya menjual huma/padi). Jika pelaku tak punya harta, maka pertanggungjawaban dibebankan pada keluarga si pelaku.

Pertanggungjawaban pidana pada tindak pidana penipuan dalam hukum pidana adat Baduy tidak hanya berorientasi pada kepentingan pelaku (offender oriented) untuk diberi kesempatan memperbaiki diri dan membebaskan perasaan bersalahnya tetapi juga diorientasikan pada kepentingan korban (victim oriented) sehingga korban merupakan bagian integral dari proses penyelesaian perkara pidana.

\section{f. Penganiayaan}

Penganiayaan dalam Hukum Pidana Adat Baduy dibedakan berdasarkan berat dan ringannya penganiayaan. Jika penganiayaan tersebut bersifat ringan (mukul leutik/mukul sedikit) maka cukup diselesaikan antara para pihak, silih ngahampura/saling memaafkan yang dimediatori jaro tangtu. Namun jika penganiayaan tersebut bersifat berat maka penyelesaiannya melibatkan sistem hukum pidana adat Baduy dengan memperhatikan asas ultimum remedium.
Meski demikian, menurut Saidam, tokoh pemuda Kampung Kadu Ketug III (Baduy Luar) penganiayaan ataupun perkelahian jarang sekali terjadi di Baduy. Jika ada indikasi seseorang membenci orang lain karena suatu hal, maka selalu ada pihak ketiga yang segera memfasilitasi untuk mendamaikan. Selama ini menurut Saidam belum pernah terjadi penganiayaan di Baduy.

\section{g. Pembunuhan}

Setiap orang Baduy yang dengan sengaja melakukan pembunuhan dalam hukum pidana adat Baduy diharuskan melakukan pertobatan selama 40 kali, melaksanakan serah pati, dikeluarkan beserta keluarganya dari Baduy Dalam selama tujuh turunan dan tidak diikutsertakan dalam acara-acara adat.

\section{h. Santet (Julid)}

Menurut Jaro Sami, Julid ka papada (menyantet orang lain) adalah dosa yang sangat besar, menurut riwayat Baduy (budaya lisan yang disampaikan turun temurun) matinya pelaku julid ka papada tidak akan diterima di akhirat. Ancaman sanksi pelaku julid ka papada sama dengan pelaku incest, ditalian dibalangkeun ka laut (diikat dilemparkan ke laut).

\section{i. Sengketa Tanah}

Menurut Haji Sapin, Sekretaris Desa Kanekes, sengketa tanah adalah perkara yang paling sering terjadi di Baduy. Hal ini disebabkan karena lahan garapan di Baduy berlangsung turun temurun pada masing-masing keluarga sehingga tak 
Jurnal Law reform April 2010. Vol. 5. No.1

jarang terjadi sengketa mengenai batasbatas tanah.

5) Beberapa Tindak Pidana (Larangan) lain dalam Wilayah Baduy Dalam dan Baduy Luar

Berbagai aturan di bawah ini merupakan larangan yang hingga kini masih berlaku di Baduy khususnya Baduy Dalam sebagai aturan adat. Terhadap pelakunya jika telah melewati proses sistem peradilan pidana adat Baduy namun kemudian tetap tidak dapat melestarikan aturan adat tersebut maka dipersilahkan untuk keluar dari Baduy Dalam.

\section{a. Larangan foto dan gambar audio} visual.

Setiap orang yang berada di wilayah Baduy Dalam (Cibeo, Cikartawana, dan Cikeusik) dilarang untuk mengambil foto ataupun bentuk gambar audio visual dengan objek orang, tempat, pemandangan, rumah adat dan yang lainnya yang masih dalam wilayah Baduy Dalam.

\section{b. Larangan Merokok}

Setiap warga Baduy Dalam dilarang merokok baik di dalam wilayah Baduy Dalam maupun di luar wilayah Baduy Dalam.

\section{c. Larangan Menggunakan Emas \\ Setiap warga Baduy Dalam dilarang memakai, menyimpan dan memiliki emas baik di dalam wilayah Baduy Dalam maupun di luar wilayah Baduy Dalam.}

\section{d. Larangan Poligami dan Poliandri}

Setiap warga Baduy dilarang memiliki istri atau suami lebih dari satu orang dalam waktu bersamaan.

\section{e. Larangan Minuman Alkohol \\ Setiap warga Baduy dilarang memi-} num minuman yang mengandung alkohol atau sejenisnya yang dapat memabukan baik di dalam wilayah Baduy Dalam maupun di luar wilayah Baduy Dalam.

\section{f. Larangan Menggunakan Pakaian modern}

Setiap warga Baduy Dalam dilarang menggunakan pakaian modern sejenis kaos, kemeja dan yang lainnya yang diasosiasikan sebagai pakaian modern baik di dalam wilayah Baduy Dalam maupun di luar wilayah Baduy Dalam.

\section{g. Larangan Menggunakan Alat Mandi}

Setiap orang dilarang menggunakan alat mandi sejenis sabun, pasta gigi dan shampo di dalam wilayah Baduy Dalam.

\section{h. Larangan Menggunakan Kenda- raan}

Setiap warga Baduy Dalam dilarang menggunakan kendaraan baik di dalam wilayah Baduy Dalam maupun di luar wilayah Baduy Dalam.

\section{i. Larangan Orang asing Memasuki Wilayah Baduy Dalam \\ Setiap orang asing (luar Indonesia) dilarang memasuki wilayah Baduy Dalam.}




\section{j. Larangan Bersekolah ${ }^{51}$}

(1) Setiap warga Baduy Dalam dilarang mengenyam pendidikan sekolah formal di manapun warga Baduy berada.

(2) Setiap orang dilarang mendirikan sekolah di wilayah Baduy Dalam dan Baduy Luar.

\section{k. Larangan Mendirikan Masjid}

Setiap orang dilarang mendirikan masjid baik di dalam wilayah Baduy Dalam maupun di wilayah Baduy Luar.

\section{l. Larangan Mengolah Tanah}

\section{Menjadi Sawah}

Setiap orang dilarang mengolah tanah menjadi sawah baik di dalam wilayah Baduy Dalam maupun di wilayah Baduy Luar.

Ancaman hukuman bagi setiap orang yang melanggar ketentuan di atas bertahap mulai dari ditegor/ditegur, dipapatahan/dinasehati hingga dikeluarkan dari komunitas Baduy Dalam. Khusus untuk

\footnotetext{
51 Menurut Aman Sukarso, mantan Sekretaris Daerah Serang, setiap Seba Baduy (kunjungan warga Baduy ke pemerintahan tiap tahun) ada tiga hal yang disampaikan saat seba: minta diakui keberadaan masyarakat Baduy; minta dilindungi; minta untuk tidak boleh ada masjid, sekolah dan sawah di kawasan Baduy berdasarkan perjanjian dari dahulu. Menurut Aman Sukarso kalimat yang diucapkan selalu sama "Da Parjangjiana oge teu menang aya masigit, teu menang aya sakola, teu menang aya sawah", wawancara dengan Aman Sukarso, tanggal 23 Juli 2009. Perjanjian yang dimaksud oleh warga Baduy tersebut diduga mempunyai korelasi historis dengan perjanjian antara Kesultanan Banten yang memiliki misi menyebarkan Islam di wilayah Banten dengan warga Baduy yang diduga pelarian Kerajaan Pajajaran yang beragama Hindu. Namun demikian, perlu penelitian lebih lanjut untuk menelusuri korelasi sejarah tersebut.
}

larangan huruf i (orang asing), jika orang asing tersebut telah sempat masuk ke wilayah Baduy Dalam, maka wilayah Baduy Dalam tersebut harus dibersihkan dengan upacara nyapuan. Dalam hal pernikahan (larangan huruf $\mathrm{d}$, poligami/poliandri) warga Baduy dilarang memiliki istri atau suami lebih dari satu orang dalam waktu bersamaan. Bagi warga Baduy luar jika ingin menikahi perempuan lain selain istrinya maka istrinya yang terdahulu harus diceraikan. Sementara pada warga Baduy Dalam pernikahan merupakan ikatan suami istri hingga kematian yang hanya dapat memisahkan ikatan tersebut. Jika salah satu pasangan telah meninggal maka dibolehkan janda atau duda tersebut menikah lagi. ${ }^{52}$

\section{B. Peran Hukum Pidana Substantif} Adat Baduy dalam Memberikan Kontribusi pada Pembaharuan Hukum Pidana Nasional.

1. Perkembangan Pembaharuan $\mathrm{Hu}$ kum Pidana Nasional

Sebagaimana diuraikan dalam bab II, pembaharuan (reform) mengandung arti memperbaiki sebuah sistem dengan cara melakukan perubahan tehadap sistem

\footnotetext{
${ }^{52}$ Wawancara dengan Asep tanggal 7 Juni 2010 di Kadu Ketug III, Baduy Luar. Asep adalah penyusun buku "Saatnya Baduy Bicara" yang didasarkan pada penuturan Ayah Mursyid. Buku tersebut merupakan 'buku putih' yang mengoreksi beberapa buku yang ditulis para peneliti mengenai masyarakat Baduy. Saat wawancara berlangsung naskah buku tersebut dalam proses editing di penerbit Bumi Aksara.
} 
Jurnal Law reform April 2010. Vol. 5. No.1

tersebut. ${ }^{53}$ Pembaharuan hukum pidana nasional dalam sudut normasubstantif di Indonesia secara umum meliputi pembaharuan hukum pidana yang terdiri dari KUHP dan berbagai undang-undang khusus yang berada di luar KUHP. Pembaharuan hukum pidana nasional yang dimaksud dalam sub bab ini lebih diarahkan kepada pembaharuan hukum pidana dalam lingkup KUHP sebagai sebuah sistem hukum pidana dari sudut norma substantif. ${ }^{54}$

Pada dasarnya pembaharuan hukum pidana dalam lingkup KUHP sebagai sebuah sistem di Indonesia dilakukan dengan 2 cara: parsial dan integral. Barda Nawawi Arief mengidentifikasi pembaharuan KUHP secara parsial dilakukan dengan cara 'menambal sulam' KUHP melalui perubahan-perubahan oleh undang-undang sebagai berikut: ${ }^{55}$

a. Mencabut/menyatakan tidak berlaku lagi beberapa rumusan delik dalam KUHP.

b. Mengubah perumusan delik dalam KUHP.

c. Menambah/memasukan delik baru ke dalam KUHP.

d. Membuat perumusan delik diluar KUHP.

\footnotetext{
${ }^{53}$ Oxford Learner's Pocket Dictionary. UK. Oxford University Press.2005.Pag. 360.

${ }^{54}$ Lihat lebih lanjut dalam Barda Nawawi Arief. RUU KUHP Baru, Sebuah Restruktirisasi/ Rekonstruksi Sistem Hukum Pidana Indonesia. Semarang. Pustaka Magister 2008. HIm.3.

55 Lihat lebih lanjut dalam Barda Nawawi Arief. RUU KUHP Baru, Sebuah Restruktirisasi/ Rekonstruksi Sistem Hukum Pidana Indonesia. Semarang. Pustaka Magister 2008. HIm. 10.
}

Pembaharuan KUHP secara integral sebagai sebuah sistem dilakukan dengan cara memperbaiki KUHP tersebut melalui perubahan-perubahan terhadap sistem (KUHP) tersebut secara integral/komprehensif. Hal ini berarti perbaikan tersebut meliputi perbaikan KUHP secara utuh menyeluruh yang tidak bersifat parsial.

Tahun 1964 sebuah rancangan undang-undang (RUU) terbentuk dengan nama Asas-asas dan Dasar Pokok Tata Hukum Pidana. RUU tersebut pada dasarnya merupakan tindak lanjut dan langkah kongkret dari amanat Seminar Hukum Nasional tahun 1963. RUU tersebut merupakan embrio RUU KUHP (selanjutnya disebut konsep KUHP) yang hanya mengatur bagian umum KUHP yang direncanakan menggantikan Pasal 1 sampai dengan Pasal 103 buku I KUHP (tidak termasuk buku II dan III KUHP). Selanjutnya kemudian berturut-turut ada konsep KUHP 1971/1972, konsep KUHP 1982/1983 yang kemudian menjadi konsep 1987/1988, konsep 1991/1992, konsep 1997/1998, konsep 2004 sampai dengan 2006/2007 hingga konsep yang terakhir konsep $2008 .^{56}$

\section{Konsep KUHP yang Berkaitan dengan Hukum Pidana Adat Baduy.}

\footnotetext{
${ }^{56}$ Barda Nawawi Arif. Bunga Rampai Kebijakan Hukum Pidana Perkembangan Penyusunan Konsep KUHP Baru. Jakarta. Kencana Prenada Media. 2008. HIm. 96. Lihat juga Rancangan Undang-Undang Republik Indonesia Tentang Kitab Undang-Undang Hukum Pidana (KUHP) 2008. Jakarta. www.legalitas.org. 2008.
} 
Selain beberapa pasal tersebut, pasal lain yang berkaitan dengan hukum pidana adat Baduy adalah sebagai berikut:

Pasal 55 ayat 1 huruf $\mathrm{j}$ dan $\mathrm{k}$

(1) Dalam pemidanaan wajib dipertimbangkan :

j.Pemaafan dari korban dan/atau keluarganya; dan /atau

k.Pandangan masyarakat ter ${ }^{57}$ hadap tindak pidana yang dilakukan mengenai pedoman pemidanaan.

Pasal 55 ayat 1 huruf $\mathrm{j}$ dan $\mathrm{k}$ adalah hal-hal yang wajib diperhatikan hakim dalam menjatuhkan pidana (pedoman pemidanaan). Pemaafan dalam formulasi pasal 55 ayat 1 huruf $\mathrm{j}$ identik dengan konsep silih ngahampura (saling memaafkan) dalam hukum pidana adat Baduy yang merupakan bagian dari sistem penyelesaian perkara di Baduy. ${ }^{58}$ Perbedaannya adalah pemaafan dalam Pasal 55 ayat $1 \mathrm{j}$ hanya sebagai hal yang wajib diperhatikan hakim dalam melakukan pemidanaan sehingga dimungkinkan untuk tidak menjatuhkan pidana (rechterlijke pardon). Dalam hukum

\footnotetext{
${ }^{57}$ Menurut Saidam, warga Baduy Luar yang menjadi guide mengantar peneliti ke Cibeo Baduy Dalam, pada umumnya orang asing mengerti dan menghormati larangan tersebut. $\mathrm{Hal}$ ini misalnya dialami Saidam saat bertemu orang Perancis satu bulan lalu (Maret 2010), dan kemudian hanya mengunjugi Kampung Gajeboh Baduy Luar. Namun menurut Devi Naufal Halwany, ayahnya (Alm. Halwany Michrob, sejarawan Banten) pernah mengantarkan orang asing ke wilayah Baduy ${ }_{58}$ Dalam.

58 Konsep silih ngahampura ini identik dengan ritus mela sareka di masyarakat Lamaholot, Flores Nusa Tenggara Timur. Mela sareka adalah suatu ritus perdamaian dalam adat Lamaholot dalam menyelesaikan kasus sengketa. Lihat dalam pemarapan Bab I.
}

pidana adat Baduy konsep silih ngahampura selain dapat dijadikan pertimbangan untuk Jaro Tangtu tidak menjatuhkan hukuman (terhadap tindak pidana yang bersifat ringan) juga sebagai hal yang wajib dicapai (dipenuhi) dalam penyelesaian perkara sehingga keharmonisan kembali terjaga. Dalam konteks ini kesimpulan Artidjo Alkotsar yang termuat dalam peryataannya menjadi relevan: ${ }^{59}$

Penyelesaian perkara dalam hukum adat senantiasa bertumpu pada penyelesaian perkara, bukan pada memutus perkara sebagaimana yang terjadi dalam acara hukum Eropa atau Barat. Dengan demikian, setelah ada penyelesaian dalam perkara adat maka hubungan personal, kekeluargaan komunitas pada masyarakat adat tetap terjaga. Sedangkan dalam hukum Eropa atau Barat, setelah diputusnya sengketa oleh pengadilan, maka putus pula hubungan keluarga mereka yang bersengketa tersebut.

Salah satu wujud dari penyelesaian tindak pidana yang juga berorientasi pada kepentingan korban (victim oriented) dalam hukum pidana adat Baduy adalah kewajiban dicapainya silih ngahampura.

Pasal 55 ayat 2

\footnotetext{
${ }^{59}$ Artidjo Alkostar dalam Anto Soemarman Hukum Adat, Perspektif Sekarang dan Mendatang. Yogyakarta. Adicita Karya Nusa. 2003. HIm v-vii.
} 
Jurnal Law reform April 2010. Vol.5. No.1

(2) Ringannya perbuatan, keadaan pribadi pembuat atau keadaan pada waktu dilakukan perbuatan atau yang terjadi kemudian, dapat dijadikan dasar pertimbangan untuk tidak menjatuhkan pidana atau mengenakan tindakan dengan mempertimbangkan segi keadilan dan kemanusiaan.

Penjelasan pasal ini menyatakan bahwa ketentuan di atas merupakan asas rechterlijke pardon yang memberi kewenangan kepada hakim untuk memberi maaf pada seorang yang bersalah melakukan tindak pidana yang sifatnya ringan (tidak serius).

Ketentuan mengenai rechterlijke pardon (permaafan hakim) juga terdapat di Baduy. Menurut Ayah Mursyid, terhadap perbuatan-perbuatan yang ringan yang bisa diselesaikan antara pihak keluarga yang melibatkan Jaro Tangtu dalam penyelesaiannya, jika kemudian kedua pihak sudah saling memaafkan (silih ngahampura) maka Jaro Tangtu tidak menjatuhkan hukuman apa-apa. Namun ketentuan tersebut tidak berlaku pada tindak pidana yang memerlukan pembersihan batiniah ngabokoran atau serah pati. Maka dengan demikian konsep mengenai rechterlijke pardon di Baduy dan konsep KUHP sama, yakni dilakukan terhadap tindak pidana yang bersifat ringan.

\section{Pasal 11}

(1) Untuk dinyatakan sebagai tindak pidana, selain perbuatan tersebut di- larang dan diancam pidana oleh peraturan perundang-undangan, harus juga bersifat melawan hukum atau bertentangan dengan kesadaran hukum masyarakat.

Pasal 11 tersebut merupakan ketentuan untuk mengukur dan menentukan suatu perbuatan disebut sebagai tindak pidana. Ketentuan tersebut merupakan implementasi asas sifat melawan hukum (baik formil maupun materil). Ukuran sifat melawan hukum formil ditentukan dengan suatu perbuatan tersebut dilarang dan diancam pidana oleh peraturan perundang-undangan. Sementara ukuran sifat melawan hukum materil adalah bersifat melawan hukum atau bertentangan dengan kesadaran hukum masyarakat.

Pada dasarnya perumusan pasal diatas bertitik tolak dari asas tiada pertanggungjawaban tanpa sifat melawan hokumIno liability without unlawfullness yang kemudian mempunyai turunan asas ketiadaan sama sekali sifat melawan hukum secara materiel/Afwezigheid van alle materiele wederrechtelijkheid (AVAW). ${ }^{60}$

Penegasan asas AVAW yang mewujud dalam Pasal 11 tersebut membuat penegak hukum khususnya hakim harus melihat apakah suatu perbuatan bertentangan dengan sifat melawan hukum atau bertentangan dengan kesadaran hukum masyarakat selain bertentangan

\footnotetext{
${ }^{60}$ Lihat dalam paparan bab II dan Barda Nawawi Arief. RUU KUHP Baru Sebuah Restrukturisasi/Rekonstruksi Sistem Hukum Pidana Indonesia. Semarang: Badan Penerbit Undip. 2008, hlm.30.
} 
dengan peraturan perundang-undangan. Adanya AVAW dalam suatu tindak pidana menjadi alasan pembenar yang dapat menghapuskan pidana ${ }^{61}$ Sifat melawan hukum materil sebagaimana dipaparkan dalam Bab II memiliki fungsi, yang salah satunya berfungsi negatif. Hal ini berarti sekalipun jika suatu perbuatan bertentangan dengan peraturan perundang-undangan namun tidak bertentangan dengan sifat melawan hukum (materil), maka dalam konteks fungsinya yang negatif sifat melawan hukum formil menjadi hapus oleh tidak adanya sifat melawan hukum materil (AVAW). ${ }^{62}$

Dalam hukum pidana adat Baduy keberadaan AVAWpun diakui. Hal ini diketahui dalam paparan Jaro Dainah saat menjelaskan tindak pidana pencurian sebagai berikut :

Dalam pencurian dilihat alasan dia mencuri, kalau karena kelaparan nggak papa, mengambil mangga saliwat (selewat) 1 atau 2 buah gak papa, jadi

\footnotetext{
${ }^{61}$ AVAW dibedakan dengan AVAS (Afwezigheid van Alle Schuld/ketiadaan kesalahan) yang merupakan alasan pemaaf dalam suatu tindak pidana. AVAS adalah turunan dari asas kesalahan Geen Straf zonder schuld (tiada pidana tanpa kesalahan) (Belanda); "Keine straf ohne schuld" (Jerman); No Liability without blameworthiness (Inggris); dalam bahasa latin dikenal sebagai Actus non facit, nisi mens sit rea (An act doesn't make a person guilty, unless the mind is guilty); asas ini kemudian memiliki turunan asas Afwezigheids van alle schuld (AVAS)Lihat lebih lanjut dalam Ferry Fathurokhman. Pengakuan Asas Legalitas Materil dalam Rancangan Undang-Undang KUHP sebagai lus Constituendum. Jurnal IImu Hukum Litigasi. Fakultas Hukum Universitas Pasundan.Volume 10 Nomor 3.Oktober 2009.

${ }_{62}$ Mengenai konsep dasar AVAW lihat dalam paparan Bab II.
}

dilihat faktor pencuriannya. Beda dengan ngambil mangganya sekilo dua kilo.

Pasal selanjutnya yang berkaitan dengan hukum pidana adat Baduy adalah Pasal 116 ayat 1 huruf a mengenai pidana verbal sebagai salah satu pidana pokok bagi anak dan Pasal 116 ayat 2 huruf $\mathrm{c}$ mengenai pemenuhan kewajiban adat sebagai salah satu pidana tambahan bagi anak. Redaksional lengkap pasal 116 ayat 1 huruf a tersebut adalah sebagai berikut:

\section{Pasal 116}

(1) Pidana pokok bagi anak terdiri atas:
a. Pidana verbal.
1.Pidana peringatan; atau
2. Pidana teguran keras

Hukum pidana adat Baduy mengenal jenis pidana verbal sebagai ditegor (ditegur) dan dipapatahan (dinasehati). Pidana verbal dalam hukum pidana adat Baduy berlaku sebagai jenis pidana yang dapat diberlakukan umum (tidak hanya pada anak). Hal ini dirasakan efektif mengingat masyarakat adat Baduy yang masih bersifat guyub, komunal, sehingga jenis pidana verbal masih efektif dan relevan diberlakukan pada orang dewasa.

\section{Pasal 116}

(2) Pidana tambahan (bagi anak.pen) terdiri atas :
a.......
b......
c. pemenuhan kewajiban adat. 
Jurnal Law reform April 2010. Vol. 5. No.1

Perumusan pemenuhan kewajiban adat sebagai pidana tambahan (baik khusus bagi anak;Pasal 116 ayat $2 \mathrm{c}$, maupun sebagai jenis pidana tambahan umum; Pasal 67 ayat 1 e) merupakan wujud dari pengakomodiran hukum adat dalam Konsep KUHP sebagaimana diamanahkan berbagai seminar hukum nasional.

Selanjutnya bentuk pengakomodiran hukum adat juga terlihat dalam Pasal 145 Konsep KUHP 2008 mengenai gugurnya kewenangan penuntutan sebagai berikut:

\section{Pasal 145}

Kewenangan penuntutan gugur, jika:

a. telah ada putusan yang memperoleh kekuatan hukum tetap;

b. terdakwa meninggal dunia;

c. daluwarsa;

d. penyelesaian di luar proses;

e. $\ldots$.

f. $\quad \ldots$

g. $\quad \ldots$

.... (cetak tebal dari peneliti)

Dengan adanya pengaturan penyelesaian di luar proses sebagai salah satu syarat gugurnya kewenangan penuntutan, maka kepentingan hukum adat di seluruh Indonesia dapat dimungkinkan terakomodir ke dalam Pasal 145d. Dikatakan dapat dimungkinkan terakomodir karena ketentuan lebih lanjut mengenai penyelesaian di luar proses tersebut belum ada, demikian halnya dalam bagian penjelasan, tidak ada penjelasan lebih lanjut mengenai ketentuan Pasal 145d. Hal ini berbeda dengan beberapa ketentuan lain mengenai gugurnya kewenangan penuntutan yang beberapanya telah ada pengaturan lebih lanjutnya seperti daluwarsa ditentukan lebih lanjut dalam Pasal 149, Pasal 145a ditentukan lebih lanjut dalam Pasal 147. ${ }^{63}$ Menurut Barda Nawawi Arief, ketentuan lebih rinci mengenai penyelesaian di luar proses sebagai dasar yang menggugurkan kewenangan penuntutan seyogyanya akan diatur lebih lanjut dalam RUU KUHAP (Rancangan Undang-Undang Kitab Undang-Undang Hukum Acara Pidana). ${ }^{64}$

\section{Kontribusi Hukum Pidana Adat Baduy terhadap Pembaharuan Hukum Pidana (Konsep KUHP)}

Pembahasan dalam permasalahan pertama mengenai hukum pidana adat Baduy memberikan beberapa gambaran yang patut dipertimbangkan untuk 'diangkat' menjadi hukum pidana nasional, beberapa diantaranya adalah sebagai berikut:

\section{a. Santet (Julid)}

Konsep KUHP 2008 telah mengakomodir tindak pidana yang berkaitan dengan santet (bukan tindak pidana santet) dalam Pasal $293^{65}$ sebagai berikut

\section{Pasal 293}

\footnotetext{
${ }^{63}$ Lihat lebih lanjut dalam Konsep KUHP 2006 atau Konsep KUHP 2008.

Barda Nawawi Arief. Mediasi Penal, Penyelesaian Perkara di Luar Pengadilan. Semarang. Pustaka Magister. 2008. HIm 49.

${ }^{65}$ Pasal 292 dalam Konsep KUHP 2004.
} 
(1) Setiap orang yang menyatakan dirinya mempunyai kekuatan gaib, memberitahukan, menimbulkan harapan, menawarkan atau memberikan bantuan jasa kepada orang lain bahwa karena perbuatannya dapat menimbulkan penyakit, kematian, penderitaan mental atau fisik seseorang, dipidana dengan tindak pidana penjara paling lama 5 (lima) tahun atau denda paling banyak kategori IV ${ }^{66}$

(2) Jika pembuat tindak pidana sebagaimana dimaksud pada ayat (1) melakukan perbuatan tersebut untuk mencari keuntungan atau menjadikan sebagai mata pencaharian atau kebiasaan, maka pidananya dapat ditambah dengan $1 / 3$ (satu per tiga)

Perumusan tindak pidana yang berkaitan dengan santet ini pernah dan masih mendapat kritikan dari beberapa kalangan. Diantara yang tidak setuju dengan perumusan tindak pidana ini adalah J.E Sahetapy. Pada dasarnya ketidaksetujuan Sahetapy dilandaskan pada kesulitan pembuktian dan anggapan perumusan ini merupakan kemunduran berpikir kembali ke abad pertengahan di Eropa. ${ }^{67}$ Dalam

\footnotetext{
66 Rp 75.000.000,00 (tujuh puluh lima juta rupiah), lihat dalam Pasal 80 Konsep KUHP 2008.

67 J.E.Sahetapy. KUHP, Santet, dan Zina. Jawa Pos edisi Selasa, 18 November 2003. Diunduh dari http://www.oocities.com/latoehalat/jawapos1 91103.htm, diakses tanggal 30 Mei 2010. Lebih lanjut Sahetapy menuliskan agar dicantumkan pro memorie bertalian dengan sikap penolaknnya terhadap santet.
}

uraiannya lebih lanjut Sahetapy juga meragukan keampuhan santet. ${ }^{68}$

Menurut Barda Nawawi Arief, perumusan pasal yang berkaitan dengan santet dalam Konsep KUHP diatas (Pasal 293), merupakan perluasan jangkauan dari Pasal 162 dalam KUHP yang saat ini berlaku tentang penawaran bantuan (keterangan/kesempatan/sarana) untuk melakukan tindak pidana ${ }^{69}$ yang redaksional lengkapnya berbunyi sebagai berikut :
Pasal 162
Barangsiapa di muka umum, dengan lisan atau tulisan menawarkan untuk memberi keterangan, kesempatan atau sarana guna melakukan perbuatan pidana, diancam dengan pidana pen- jara paling lama sembilan bulan atau denda paling banyak tiga ratus rupiah

Dalam Konsep KUHP 2008, Pasal 162 KUHP tersebut mejadi Pasal 291 dan

\footnotetext{
${ }^{68}$ Dalam artikel yang sama, Sahetapy menuliskan sebagai berikut: "Lagi pula, kalau santet itu ampuh, mengapa para koruptor tidak disantet saja?"

${ }^{69}$ Dalam KUHP bentuk bantuan yang lebih khusus dan berdiri sendiri secara tersebar diatur dalam berbagai pasal seperti Pasal 333 (4) Memberi tempat untuk perampasan kemerdekaan yang melawan hukum; Pasal 345 memberi sarana untuk bunuh diri; Pasal 349 tabib, dokter/bidan, juru obat yang melakukan atau membantu melakukan delik-delik abortus provocatus; Pasal 415 menolong/membantu seorang pejabat yang menggelapkan uang atau surat berharga; dan Pasal 417 menolong/membantu seorang pejabat yang menggelapkan, menghancurkan, merusak atau membuat tidak dapat dipakai barang-barang bukti. Lihat lebih lanjut dalam Barda Nawawi Arief. Bunga Rampai Kebijakan Hukum Pidana, Perkembangan Penyusunan Konsep KUHP Baru. Jakarta. Kencana Prenada Media. 2008. HIm 297.
} 
Jurnal Law reform April 2010. Vol. 5. No.1

$292^{70}$ mengenai Penawaran untuk Melakukan Tindak Pidana sebagai berikut:

\section{Pasal 291}

Setiap orang dimuka umum dengan lisan atau tulisan menawarkan untuk memberi keterangan, kesempatan, atau sarana untuk melakukan tindak pidana, dipidana dengan pidana penjara paling lama 1(satu) tahun atau denda paling banyak kategori III. ${ }^{71}$

Pasal 292

(1) Setiap orang yang menyiarkan, mempertunjukan, atau menempelkan tulisan atau gambar sehingga terlihat oleh umum, atau memperdengarkan rekaman sehingga sehingga terdengar oleh umum, yang berisi penawaran untuk keterangan, kesempatan atau sarana guna melakukan tindak pidana dengan maksud agar penawaran tersebut diketahui atau lebih diketahui oleh umum, dipidana dengan pidana penjara paling lama 1 (satu) tahun atau denda paling banyak kategori III.

b. Konsep Pertanggungjawaban Pelaku yang Menderita Kelainan Jiwa

Penjelasan lebih sederhana mengenai vicarious liability dikemukakan oleh Alan C. Michaels sebagai berikut: ${ }^{72}$

70 Pasal 221 dan 222 dalam Konsep KUHP 1991/1992

Pidana denda kategori III adalah Rp. $30.000 .000,00$, lihat lebih lanjut dalam Pasal 80 Konsep KUHP 2008.

72 Alan C Michaels dalam http://law.jrank.org/pages/2255/VicariousLiability.html
Vicarious liability, which is common in some areas of the law, refers to legal responsibility for the actions of another. If a law holds $X$ responsible for $Y^{\prime}$ s actions, then $X^{\prime}$ s liability is said to be vicarious.

Vicarious liability menurut Alan menunjuk pada pertanggungjawaban hukum atas perbuatan orang lain. Jika ketentuan hukum menetapkan $\mathrm{X}$ bertanggungjawab atas perbuatan $\mathrm{Y}$, maka pertanggungjawaban $\mathrm{X}$ tersebut dikatakan/disebut sebagai vicarious. Lebih lanjut Alan mengemukakan bahwa terkadang terminologi vicarious liability sengaja ditujukan hanya pada kasus-kasus yang menentukan pertanggungjawaban pidana $\mathrm{X}$ atas perbuatan $\mathrm{Y}$ berdasarkan hubungan antara X dan Y. Alan kemudian menegaskan bahwa $\mathrm{X}$ pada dasarnya tidak memiliki kesalahan, $X$ menanggung kesalahan $\mathrm{Y}$ karena adanya hubungan (relationship) antara X dan Y.

\section{c. Ganti Rugi}

Konsep ganti rugi dalam hukum pidana adat Baduy melekat pada setiap tindak pidana yang pada hakikatnya menimbulkan korban. Ganti rugi (kepada pihak korban) dalam hukum pidana adat Baduy menjadi semacam pidana pokok yang wajib dipenuhi oleh pihak pelaku sehingga silih ngahampura dapat tercapai. Hal ini dikecualikan jika korban melepaskan haknya dalam mendapatkan 
ganti rugi karena tercapainya silih ngahampura tanpa permintaan ganti rugi ataupun menolak menerima ganti rugi. (community oriented) sehingga keseimbangan dalam masyarakat kembali terjaga.

\section{BAB IV}

KESIMPULAN DAN SARAN

\section{A. Kesimpulan}

Pembahasan pada permasalahan yang disajikan dalam bagian hasil penelitian dan pembahasan menunjukkan beberapa kesimpulan sebagai berikut:

\section{A.1 Sistem Hukum Pidana Substantif Adat Baduy}

1. Sebagaimana sebuah sistem hukum pidana substantif pada umumnya, hukum pidana adat Baduy memiliki sistem hukum pidana substantif yang meliputi hukum formil/prosedural, hukum materiel/susbtantif dan hukum pelaksanaan pidana.

2. Perumusan tindak pidana, pertanggungjawaban dan sanksi dalam hukum pidana substantif adat Baduy dirumuskan secara tidak tertulis dan tidak dikodifikasikan dalam sebuah kitab. Pengetahuan dan pemahaman hukum pidana substantif adat Baduy diles tarikan melalui budaya lisan tutur secara turun temurun.

3. Konsep pertanggungjawaban sanksi hukum dalam Hukum pidana substantif adat Baduy diorientasikan pada penyelesaian perkara secara integral yang meliputi pemulihan kepentingan korban (victim oriented), kepentingan pelaku (offender oriented) dan kepentingan masyarakat

\section{A.2. Peran Hukum Pidana Substantif} Adat Baduy dalam Memberikan Kontribusi pada Pembaharuan Hukum

\section{Pidana Nasional}

1. Konsep KUHP 2008 dalam konteks pembaharuan hukum pidana pada dasarnya telah mengakomodir berbagai nilai-nilai universal dalam hukum adat sebagaimana amanah berbagai seminar hukum nasional, dokumen internasional dan para ahli hukum. Konsep KUHP 2008 selain diorientasikan pada pelaku (offender oriented) juga telah mengakomodir kepentingan korban (victim oriented) pada beberapa bagiannya.

2. Hukum Pidana Substantif Adat Baduy memiliki ketentuan mengenai konsep pelaku santet, konsep pertanggung jawaban pelaku berkelainan jiwa dan konsep ganti rugi yang diorientasikan pada kepentingan hukum korban dan masyarakat yang belum diakomodir dalam Konsep KUHP 2008.

\section{B. Saran}

Berdasarkan hasil penelitian dan pembahasan, beberapa saran yang patut dipertimbangkan berkaitan dengan hukum pidana adat Baduy dan pembaharuan hukum pidana nasional adalah sebagai berikut:

1. Hukum pidana adat Baduy perlu dipertimbangkan untuk dibuat dalam 
Jurnal Law reform April 2010. Vol.5. No.1

bentuk tertulis sehingga konsistensi pengetahuan dan pemahaman mengenai hukum pidana adat Baduy dapat merata dalam kalangan masyarakat Baduy.

2. Sebagaimana hukum pidana adat Baduy, pembaharuan hukum pidana nasional hendaknya mengorientasikan penyelesaian perkara pidana secara integral yang meliputi pengakomodiran kepentingan korban, kepentingan pelaku dan kepentingan masyarakat.

3. Tindak pidana yang berkaitan dengan santet sebagaimana terdapat dalam hukum pidana adat Baduy dan konsep KUHP 2008 hendaknya tetap dipertahankan keberadaannya dan mempertimbangkan untuk mengkriminalisasikan dan memformulasikan tindak pidana santet yang dilakukan oleh orang yang memiliki kemampuan santet atas inisiatif sendiri mengingat eksistensi dan fenomena santet yang menimbulkan keresahan dalam masyarakat.

4. Konsep pertanggungjawaban pelaku yang menderita kelainan jiwa sebagaimana dalam hukum pidana adat Baduy hendaknya diadopsi Konsep KUHP dalam konteks pembaharuan hukum pidana.

5. Konsep ganti rugi sebagaimana ada dalam hukum pidana adat Baduy yang melekat kepada setiap tindak pidana hendaknya diadopsi Konsep KUHP dan selalu diperhatikan hakim sehingga penyelesaian perkara pidana secara integral dapat terlaksana.

6. Nilai-nilai universal hukum adat yang telah diakomodir dalam pembaharuan hukum pidana nasional hendaknya dipertahankan dengan berdasarkan pada kajian-kajian hukum adat secara berkesinambungan.

\section{DAFTAR PUSTAKA}

Ali, Achmad. Menguak Teori Hukum (Legal Theory) dan Teori

Peradilan(Judicialprudence)Termasuk Interpretasi Undangundang Legisprudence), (Volume 1, Pemahaman Awal). Jakarta.

Kencana Prenada Media Group. 2009. Amirudin dan Zainal Asikin. Pengantar Metode Penelitian Hukum. Jakarta. PTRaja Grafindo. 2004.
Arief, Barda Nawawi. Pelengkap Bahan Kuliah Hukum Pidana I. Semarang. Yayasan Sudarto. 1990. Bunga Rampai Kebijakan Hukum Pidana. Bandung. Citra Aditya Bakti.2002.

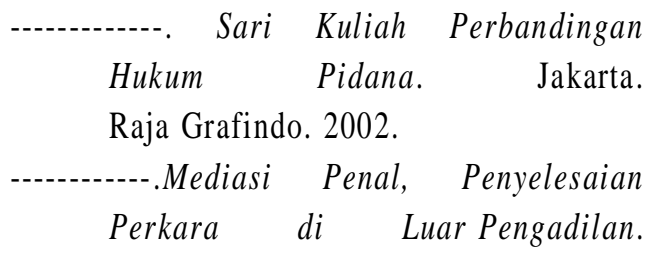

Semarang. Pustaka Magister. 2008. 
--------.. Kebijakan Legislastif dalam Penanggulangan Kejahatan dengan

Pidana Penjara. Semarang. Badan Penerbit Undip. 2000. - Beberapa Aspek Pengembangan

Ilmu Hukum Pidana (Menyongsong

Generasi Baru Hukum Pidana

Indonesia). Semarang. Badan

Penerbit Undip. 2007.

. Bunga Rampai Kebijakan Hukum

Pidana, Perkembangan Penyusunan

Konsep KUHP Baru. Jakarta.

Kencana Prenada Media. 2008.

Kumpulan Hasil Seminar

Hukum Nasional ke I s/dVIII dan

Konvensi Hukum Nasional. Semarang.

Pustaka Magister. 2008.

- Perkembangan Asas Hukum

Pidana Indonesia. Semarang. Penerbit

Pustaka Magister Undip. 2008 RUU KUHP Baru,

Sebuah Restrukturisasi/Rekonstruksi

Sistem Hukum Pidana

Indonesia. Semarang. Pustaka

Magister. 2008.

Tujuan dan Pedoman

Pemidanaan, Perspektif Pembaharuan

Hukum Pidana dan Perbandingan

Beberapa Negara. Semarang. BP

Undip. 2009

Braithwaite, John. Restorative Justice and

Responsive Regulation. New York.

Oxford University Press. 2002.

Davidson, Jamie S, and David Henley. The

Revival of Tradition in Indonesian

Politics: The Deployment of Adat

Colonialism to Indigenism. Routledge
Contemporary Southeast Asia Series.

London. 2007.

Dinas Informasi, Komunikasi, Seni Budaya dan Pariwisata Kabupaten Lebak. MembukaTabir Kehidupan Tradisi Budaya Masyarakat Baduydan Cisungsang Serta Peninggalan Sejarah Situs Lebak Sibedug. 2004.

Enschede, Ch.J, dan A. Heijder (terjemahan R Achmad Soema Dipradja). AsasAsas Hukum Pidana. Bandung. Almuni. 1982.

Friedman, Lawrence Meir. The Legal System. A Social Science Perspective. Russel Sage Foundation. New York. 1975.

---------. The Horizontal Society. London.Yale University Press. 1999.

Gautama, Sudargo dan Robert N Hornick. An Introduction to IndonesianLaw, Unity in Diversity. Bandung. Alumni. 1983.

Hadisuprapto, Paulus. Delinkuensi Anak, Pemahaman dan Penanggulangannya. Malang. Bayu Media. 2008.

Hamzah, Andi. Asas-asas Hukum Pidana.Jakarta. Rineka Cipta. 1994

Hartono, Soenaryati. Dari Hukum Antar Golongan ke Hukum Antar Adat. Bandung. Citra Aditya Bakti. 1981.

--------. Penelitian Hukum diIndonesia pada akhir abad ke-20. Bandung. Alumni. 1994.

Haveman, Roelof H. The Legality of Adat Criminal Law in Modern Indonesia. Jakarta. Tatanusa. 2002. 
Jurnal Law reform April 2010. Vol.5. No.1

Hadikusumah, Hilman. Pokok-pokok Pengertian Hukum Adat. Bandung. Alumni. 1980.

Jonkers, J.E. Buku Pedoman Hukum Pidana Hindia Belanda. Jakarta. Bina Aksara. 1987.

Kanter, E.Y. dan S.R.Sianturi.Asas-asas Hukum Pidana di Indonesia dan Penerapannya.Jakarta. Storia Grafika.2002.

Kartika, Sandra dan Candra Gautama. Menggugat Posisi Masyarakat Adat Terhadap Negara. Yogyakarta. Pustaka Pelajar. 1999.

Ketut Sutha, I Gusti. Bunga Rampai Beberapa Aspekta Hukum Adat. Yogyakarta. Liberty.1987.

Kelsen, Hans. Pengantar Teori Hukum. Bandung. Nusa Media. 2008.

Lamintang, P.A.F. Dasar-dasar Hukum Pidana Indonesia. Bandung. Sinar Baru. 1984.

Lembaga Informasi Nasional Republik Indonesia. Persandingan UndangUndang Dasar Negara Republik Indonesia Tahun 1945. 2002.

Mahadi. Uraian Singkat Tentang Hukum Adat Sejak RR Tahun 1854. Bandung. Alumni. 1991

Michrob, Halwany. The Way of Life: Suku Baduy as a Cultural Interest. Jakarta. Asean Writer Workshop. 1996.

Moeljatno. Fungsi dan Tujuan Hukum Pidana Indonesia dan Rencana Undang-undang Tentang Asas-asas dan Dasar-dasar Pokok Tata Hukum Indonesia. Jakarta. Bina Aksara.1985. Asas-asas Hukum Pidana. Jakarta. Rineka Cipta. 2002.

Moloeng, Lexi J. Metodologi Penelitian Kualitatif. Bandung. Rosda Karya.2007

Morris, Allison and Gabrielle Maxwell. Restorative Justice for Juveniles, Conferencing,Mediation and Circles. North America (US and Canada). Hart Publishing. 2001.

Muhyidin, Mansyur. Banten Menuju Masa Depan. Cilegon. Yayasan Kiyai Haji Wasyid. 1999.

Muladi dan Barda Nawawi Arief. Teori-teori dan Kebijakan Pidana. Bandung. Alumni. 2005.

Nasution, S. Metode Research. Penerbit Jemars.tt.

Nyoman Serikat Putra Jaya. Relevansi Hukum Pidana Adat dalam Pembaharuan Hukum Pidana. Bandung. Citra Aditya Bakti. 2005.

Kapita

Selekta Hukum Pidana. Semarang. BP Undip. 2005.

Gofar, Fajrimei A. Position Paper Advokasi RUU KUHP, Asas Legalitas dalam Rancangan KUHP 2005. Jakarta. ELSAM. 2005.

Permana, R. Cecep Eka Tata Ruang Masyarakat Baduy. Jakarta. Wedatama Widya Sastra. 2006. 
Pujirahayu, Esmi Warassih. Pranata Hukum, Sebuah Telaah Sosiologis. Semarang. Suryandaru Utama. 2005.

Pujiyono. Kumpulan Tulisan Hukum Pidana. Bandung. Mandar Maju.2007.

Rahardjo, Satjipto. Ilmu Hukum. Bandung.

Citra Aditya Bakti. 2006. Negara Hukum yang

Membahagiakan

Rakyatnya. Yogyakarta.Genta Press. 2008.

\section{Biarkan}

Mengalir.

Hukum

Kritis tentang Peroulatan Manusia dan Hukum. Penerbit Buku Kompas, 2007.

Hukum dalam Jagat

Ketertiban. Jakarta. UKI Press. 2006.

Rato, Dominikus. Pengantar Hukum Adat. Yogyakarta. LaksBang Pressindo. 2009.

Remmelink, Jan. Hukum Pidana, Komentar atas Pasal-Pasal Terpenting dari Kitab Undang-Undang Hukum Pidana Belanda dan Padanannya dalam Kitab Undang-Undang Hukum Pidana Indonesia. Jakarta.Gramedia Pustaka Utama. 2003.

Santoso, Topo. Menggagas Hukum Pidana Islam, Penerapan Syariat Islam dalam Konteks Modernitas. Bandung. Assyamil.2000.

Sapardjaja, Komariah Emong. Ajaran Sifat Melawan Hukum Materiel dalam Hukum Pidana Indonesia. Bandung. Penerbit Alumni. 2002.
Soekanto. Meninjau Hukum Adat Indonesia, Suatu Pengantar untuk Mempelajari Hukum Adat. Jakarta. Rajawali Press. 1985.

------. Meninjau Hukum Adat Untuk Mempelajari Hukum Adat. Jakarta. Raja Grafindo Persada.1996.

Soekanto dan Soerjono Soekanto. Pokokpokok Hukum Adat. Bandung. Alumni. 1978.

Soekanto, Soerjono. Pengantar Penelitian Hukum. Jakarta. UI Press.2008.

Soekanto, Soerjono dan Sri Mamudji. Penelitian Hukum Normatif, Suatu Tinjauan Singkat. Jakarta. PT Raja Grafindo Persada.2007.

Soemarman, Anto. Hukum Adat. Perspektif Sekarang dan Mendatang. Yogyakarta. Adicita Karya Nusa. 2003.

Soemitro, Ronny Hanitijo. Permasalahan Hukum di dalam Masyarakat. Bandung. Alumni.1980.

Soepomo. Bab-bab Tentang Hukum Adat. Jakarta Pradnya Paramita. 1982.

Sudarto. Hukum Pidana I. Semarang: Penerbit Yayasan Sudarto. 1980.

Sudiyat, Iman. Hukum Adat, Sketsa Asas. Yogyakarta. Liberty. 1981.

Suhada. Masyarakat Baduy dalam Rentang Sejarah. Dinas Pendidikan Propinsi Banten. 2003.

Supomo, R. dan R. Djokosutono. Sejarah Politik Hukum Adat (Djilid II). Jakarta. Djambatan. 1954. 
Jurnal Law reform April 2010. Vol. 5. No.1

Tabalujan, Benny Simon. Legal Development in Developing Countries (The Role of Legal Culture). Singapore. 2001.

Ter Haar Bzn, B. Asas-asas dan Susunan Hukum Adat (Beginselen en stelsel van Adatrecht). Jakarta. Pradnya Paramita. 1981. Terjemahan K.Ng. Soebakti Poesponoto.

Tjipian, Kaum. Evolusi Pemikiran Hukum Baru: Dari Kera ke Manusia, Dari Positivistik ke Hukum Progresif. Yogyakarta. Genta Press. 2009.

Utrecht, E. Pengantar dalam Hukum Indonesia. Jakarta. PT Penerbitan Universitas. 1966. ---------. Rangkaian Sari Kuliah Hukum Pidana I. Surabaya. Pustaka Tinta Mas.1994.

Van Apeldoorn. L.J. Pengantar Ilmu Hukum. Jakarta. Pradnya Paramita. 1981.

Van Vollenhoven, Cornelis. Penemuan Hukum Adat (De ontdekking van het adatrecht). Terjemahan Koninklijk Instituut voor Taal-, LandenVolkenkunde (KITLV) bersama Lembaga Ilmu Pengetahuan Indonesia (LIPI). Jakarta. Jambatan.1981.

Wignjodipuro, Soerojo. Pengantar dan Asasasas Hukum Adat. Jakarta. Gunung Agung.1982.

Wiranata, I Gede AB. Hukum Adat Indonesia, Perkembangnya dari Masa ke Masa. Bandung. Citra Aditya Bakti. 2005.
Yani, Ahmad. Etnografi Suku Baduy. Banten. Himpunan Pramuwisata Indonesia. 2008

\section{Makalah}

Barda Nawawi Arief. Pembaharuan Sistem Penegakan Hukum dengan Pendekatan Religius dalam Konteks Siskumnas dan Bangkumnas. Makalah dalam Seminar "Menembus Kebuntuan Legalitas Formal Menuju Pembangunan Hukum dengan Pendekatan Hukum Progresif", FH UNDIP, 19 Desember 2009

\section{Jurnal}

I.G.N Sugangga. Peranan Hukum Adat dalam Pembangunan Hukum Nasional Indonesia. Jurnal MasalahMasalah Hukum. Majalah Ilmia Fakultas Hukum Universitas Diponegoro. Vol.XXXII No.2 AprilJuni 2003.

Aroma Elmina Martha. Denda Adat dalam

Penjatuhan Pidana (Studi Kasus Kekerasan di Pengadilan Negeri Merauke Papua. Jurnal Hukum Ius Quia Iustum.UII. Perkembangan Lembaga Peradilan diIndonesia. No 26 vol 112004.

Ferry Fathurokhman. Pengakuan Asas Legalitas Materiil Dalam Rancangan Undang-Undang KUHP Sebagai Ius Constituendum. Jurnal Ilmu Hukum Litigasi. FH Unpas. Volume 10 Nomor 3. Oktober 2009. 


\section{Menerebos \\ Kekakuan Legalitas Formil \\ dalam Hukum Pidana. Jurnal Hukum \\ Progresif. Program Doktor Ilmu \\ Hukum Universitas Diponegoro \\ Semarang. Volume 4/Nomor 1/April 2008.}

\section{Kamus}

Garner, Bryan A. Black's Law Dictionary. ST.Paul Minn. 1999 (seventh edition).

Oxford Learner's Pocket Dictionary. UK. Oxford University Press.2005

Departemen Pendidikan dan Kebudayaan.

Kamus Besar Bahasa Indonesia.

Jakarta. Balai Pustaka. 1994.

Dewan Redaksi Ensiklopedi Islam.

Ensiklopedi Islam. Jakarta. PT

Ikhtiar Baru Van Hoeve.1994

\section{Undang-Undang}

Undang-Undang Darurat Nomor 1 Tahun 1951 Tentang Tindakan-Tindakan

Sementara Untuk Menyelenggarakan

Kesatuan Susunan Kekuasaan dan Acara Pengadilan-Pengadilan Sipil.

Undang-Undang Nomor 73 Tahun 1958

Tentang Menyatakan Berlakunya

Undang-Undang No. 1 Tahun 1946

Republik Indonesia Tentang

Peraturan Hukum Pidana Untuk

Seluruh Wilayah Republik Indonesia dan Mengubah Kitab Undang-Undang Hukum Pidana
Undang-Undang Nomor 19 Tahun 1964

Tentang Ketentuan-Ketentuan Pokok Kekuasaan Kehakiman.

Undang-Undang Nomor 14 Tahun 1970

Tentang Ketentuan-Ketentuan Pokok

Kekuasaan Kehakiman

Undang-Undang Nomor 35 Tahun 1999

Tentang Perubahan Atas Undang-

Undang Nomor 14 Tahun 1970

Tentang Ketentuan-Ketentuan Pokok

Kekuasaan Kehakiman

Undang-Undang Nomor 23 Tahun 2000

Tentang Pembentukan Propinsi

Banten

Undang-Undang Nomor 4 Tahun 2004

Tentang Kekuasaan Kehakiman.

Undang-Undang Nomor 48 Tahun 2009

Tentang Kekuasaan Kehakiman

Undang-Undang Dasar (UUD) 1945

Rancangan Undang-Undang Republik

Indonesia Tentang Kitab Undang-

Undang Hukum Pidana (KUHP)

1997/1998. Departemen

Kehakiman Republik

Indonesia.Jakarta.1998.

Lembaga Studi dan Advokasi Masyarakat

(ELSAM). Konsep KUHP Baru 2006. Jakarta.ELSAM. 2006.

Rancangan Undang-Undang Republik

Indonesia Tentang Kitab Undang-

Undang Hukum Pidana (KUHP) 2008.

Jakarta. www.legalitas.org. 2008.

Putusan Pengadilan Negeri Rangkasbitung No 210/Pid B/2005/PNRKB. 
Jurnal Law reform April 2010. Vol.5. No.1

\section{Web Site}

www.tokohindonesia.com/ensiklopedi/b/bism ar-siregar/indeks

www.bardanawawi.wordpress.com/2009/12/2 3/pembaharuan-sistem-penegakanhukum-dengan-pendekatan-religiusdalam-konteks-siskumnas-danbangkumnas/

www.feryfaturohman.blogspot.com Kompas. Senin 27 September 2004. www.tempointeraktif.com.Penyerobotan

Tanah Baduy Merajalela. Senin $8 \mathrm{Mei}$ 2006. Diakses 2 Januari 2009.

http://www.asc41.com/6th\%20UN\%20Congr ess $\% 20$ on $\% 20$ the $\% 20$ Prevention $\% 200$ f\%20Crime $/ 021 \% 20 \mathrm{ACONF} .87 . \mathrm{BP} .5$ $\% 20 \mathrm{Human} \% 20 \mathrm{Rights} \% 20 \mathrm{and} \% 20 \mathrm{Cri}$ minal $\% 20 \mathrm{Justice} \% 20 \% 20$ Recent $\% 20$

Developments\%20in\%20Programs.pdf (Sixth United Nations Congress on the Prevention of Crime and the Treatment of Offenders. Caracas, Vezuela, 25 August to 5 September 1980). Diakses Jumat 30 Oktober 2009, Pukul 8.28.

http://www.asc41.com/9th\%20UN\%20Congr ess $\% 20$ on $\% 20$ the $\% 20$ Prevention $\% 200$ f\%20Crime $/ 010 \% 20$ ACONF. $169.8 \% 2$ 0Strengthening\%20the \% 20Rule \%20 of\%20Law.pdf (Ninth United Nations Congress on the Prevention of Crime and the Treatment of Offenders.
Cairo, Egypt, 29 April- 8 Mei 1995). Diakses Jumat 30 Oktober 2009 Pukul 8.33

http://www.anu.edu.au/fellows/jbraithwaite/l ectures/index.php

http://www.hukumonline.com/berita/baca/hol 9011/bukan-sekedar-revisi-yangdisiapkan-adalah-pembaharuan-kuhp http://legal-

dictionary.thefreedictionary.com/Vica rious+Liability, diakses tanggal 30 Mei 2010.

http://law.jrank.org/pages/2255/Vicarious Liability.html

http://www.lectlaw.com/def2/u035.htm http://www.oocities.com/latoehalat/jawapos 1 91103.htm, diakses tanggal $30 \mathrm{Mei}$ 2010.

http://www.youtube.com/watch?v=zL3m4kJb Kgo (Liputan Indosiar mengenai Noorsyaidah)

Kompas Minggu 13 Juli 2008, "Diagnosa Dokter, Noorsyaidah Alami Carpus Allenium (23)"

http://nasional.kompas.com/read/2008/07/13/ 05551553/diagnosa.dokter.n oorsy aidah.alami.carpus.allenium.23, diakses 30 Mei 2010.

http://id.wikipedia.org/wiki/Leak.

Jawa Pos Selasa, 18 November 2003. KUHP, Santet, dan Zina. Oleh J.E. Sahetapy. 